
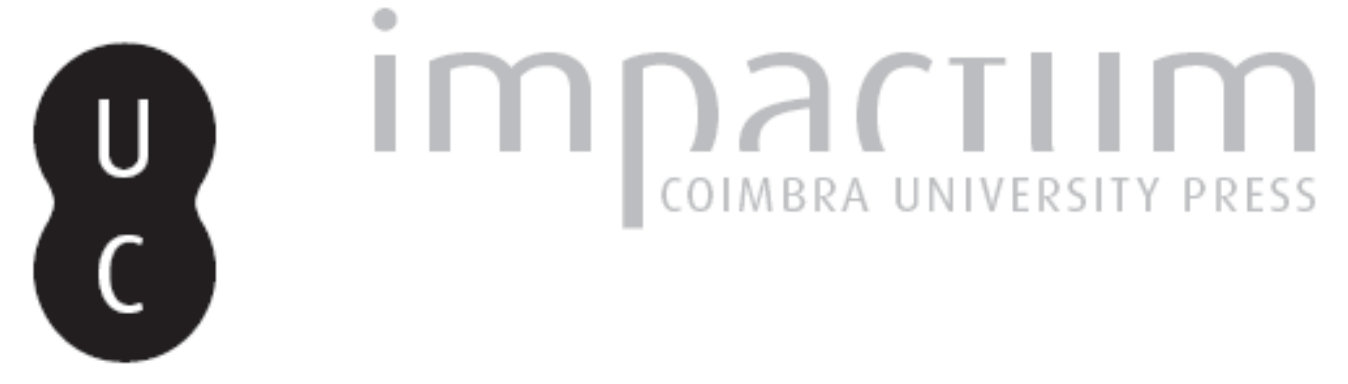

\title{
Contratempos - do amor: Filosofia, amor e melancolia
}

Autor(es): Bernardo, Fernanda

Publicado por: Faculdade de Letras da Universidade de Coimbra, Instituto de Estudos

URL

persistente: Filosóficos

DOI:

URI:http://hdl.handle.net/10316.2/35579

Accessed : $\quad$ 26-Apr-2023 13:21:34

DOI:http://dx.doi.org/10.14195/0872-0851_46_1

A navegação consulta e descarregamento dos títulos inseridos nas Bibliotecas Digitais UC Digitalis, UC Pombalina e UC Impactum, pressupõem a aceitação plena e sem reservas dos Termos e Condições de Uso destas Bibliotecas Digitais, disponíveis em https://digitalis.uc.pt/pt-pt/termos.

Conforme exposto nos referidos Termos e Condições de Uso, o descarregamento de títulos de acesso restrito requer uma licença válida de autorização devendo o utilizador aceder ao(s) documento(s) a partir de um endereço de IP da instituição detentora da supramencionada licença.

Ao utilizador é apenas permitido o descarregamento para uso pessoal, pelo que o emprego do(s) título(s) descarregado(s) para outro fim, designadamente comercial, carece de autorização do respetivo autor ou editor da obra.

Na medida em que todas as obras da UC Digitalis se encontram protegidas pelo Código do Direito de Autor e Direitos Conexos e demais legislação aplicável, toda a cópia, parcial ou total, deste documento, nos casos em que é legalmente admitida, deverá conter ou fazer-se acompanhar por este aviso.

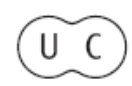




\section{REVISTA FILOSÓFICA DE COIMBRA}

vol. 23 - número 46 - outubro 2014

vol. 23 - número 46 - outubro 2014

Fundação Eng. António de Almeida

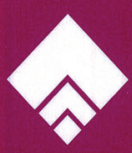




\title{
CONTRATEMPOS - DO AMOR* Filosofia, Amor e Melancolia
}

\author{
FERNANDA BERNARDO**
}

\author{
In memoriam \\ de \\ Monique Antelme \\ e da sua (ir)radiante insolência
}

Resumo: No eco do título Liebe und ihr Gebrauch/L'Amour et ses Usages do Atelier du Stage d'Hiver de l'EuroPhilosophie Erasmus Mundus, a que tenta filosoficamente responder, este ensaio faz do contratempo a própria lei do amor - ou de toda e qualquer relação ao outro como outro seja ele quem for -, salientando as ancestrais e recorrentes dificuldades da filosofia com o amor e postulando a melancolia, subtraída à ordem da consciência, da presença a si e do ego, como a Stimmung própria do amor. Romeu e Julieta e Tristão e Isolda, talvez os dois mais famosos pares aforísticos do imaginário ocidental do amor, serão aqui o testemunho por excelência da cena do contratempo e do morrer de amor(es) - bem como o testemunho da excelência de dois monumentos para o mesmo sonho de amor.

Palavras-Chave: contratempo, sonho, amor, filosofia, melancolia, Derrida.

Résumé: En écho au titre Liebe und ihr Gebrauch/L'Amour et ses Usages de l'Atelier du Stage d'Hiver de l'EuroPhilosophie Erasmus Mundus, auquel il essaye philosophiquement de répondre, cet essai prend le contretemps par la loi même de

* Conferência de encerramento do "Atelier du Stage d' Hiver de l'EuroPhilosophie Erasmus Mundus à Coimbra, Liebe und ihr Gebrauch/L'Amour et ses Usages», FLUC, 17-02-2014, originalmente com o título Contretemps - De l'amour. Philosophie, Amour et Mélancolie, a que posteriormente se acrescentaram algumas das notas e a que se desenvolveram alguns dos tópicos do segundo parágrafo.

** Professora de Filosofia na Faculdade de Letras da Universidade de Coimbra (trabalhando nas áreas da meta-ética e da Desconstrução) e tradutora de J. Derrida, E. Levinas, M. Blanchot e J.-L. Nancy: fernandabern@gmail.com. 
l'amour, ou de tout rapport à l'autre comme autre quel qu'il soit, en remarquant les ancestrales et récourrentes difficultés de la philosophie avec l'amour et en postulant la mélancolie, soustraite à l'ordre de la conscience, de la présence à soi et de l'ego, par la Stimmung même de l'amour. Roméo et Juliette et Tristan et Iseult, peut-être les deux plus fameux pairs aphoristiques de l'imaginaire occidental de l'amour, seront ici le témoignage par excellence de cette scène du contretemps e du mourir d'amour - de même que l'excellence de deux monuments pour le même rêve d'amour.

Mots-clés: contretemps, rêve, amour, philosophie, mélancolie, Derrida.

\section{$\S 1$. Sonhar o Amor - Sonhar Dizer o Amor}

«Le trait en lui-même est indiscret [...]

Il est indécent (mon amour, libère-moi du trait).

Et à ces traits obscènes j'ai tout de suite eu envie d' élever un monument, ou un château de cartes, somptueux et fragile»

J. Derrida, «Envois»

«Je reconnais que j'aime - toi - à cela : tu laisses en moi une blessure que je ne veux pas remplacer.»

J. Derrida, «Envois»

Do amor, do amor mesmo e dos seus «usos», ou talvez antes das suas misérias e dos seus esplendores, não vos irei eu falar aqui. Não o conseguiria. Não o ousaria sequer. Em que língua, aliás, o faria eu ? Aproximando o impossível, girando em torno do impossível, desafiando mesmo o impossível, coisa bem diferente será talvez tentar dar aqui a pensar filosoficamente o amor, a implacável lei (paradoxal) do amor - o que sobretudo farei na proximidade do pensamento de Jacques Derrida.

Com efeito, para além da questão filosófica que, quanto ao amor, não pode de antemão não continuar ainda hoje a colocar-se à filosofia - a saber, a questão (questão que, notemo-lo também, tem a idade da própria filosofia, de que supostamente é o espírito ou a essência, o modus próprio) «o que é («ti esti》) $o$ amor»? Esta «coisa» sem idade, tão antiga e tão nova, tão rara quanto abundante, excessiva e diversa nas suas formas e nas suas modulações, $o$ que $e ́$ ? Por outras palavras: de que é que se fala exactamente, quando se fala ou se pretende falar «do amor»? Ou «sobre o amor» e das suas figuras ou das 
suas fulgurações possíveis - a paixão, a sexualidade, o erotismo, a ternura, a amizade, a fidelidade, a fraternidade, a filialidade, a caridade, a afeição, a alegria, a adoração, o êxtase, a absolução, o dom de si, etc.? Para além da questão propriamente filosófica acerca do amor que, de antemão, não pode não continuar a colocar-se ainda hoje à filosofia, dizia - nem que seja para re-pensar a própria pré-compreensão do amor que à partida aqui nos reúne -, à guisa de exergo não posso também não começar por recordar aqui, neste incipit, quer o belo dito da Bíblia (neotestamentária) segundo o qual o amor fala uma «língua divina», «fala em línguas» diz São Paulo na sua Carta aos Coríntios, $(14,2)$, quer o dito de Jacques Derrida, em «Envois», nomeadamente, segundo o qual o amor, se o há e quando o há, passa sempre, sempre pela língua. Deve bem atravessar a língua, bem fazer a travessia da língua.

Como então bem pensar e bem dizer o amor, eis o desafio maior da minha primeira questão. Porque, se falar (do que quer que seja!) deve sempre meter-nos medo, porque, não dizendo nunca o suficiente, dizemos no entanto sempre mais, sempre demais ${ }^{1}$, a dificuldade, senão mesmo a impossibilidade de bem dizer o amor, de bem dizer o que é o amor, é à partida aqui reconhecida, ao mesmo tempo que o amor é igualmente reconhecido como a condição de possibilidade do próprio pensar e dizer em geral. É como se o amor se enviasse, se endereçasse ou tivesse de se endereçar ao mesmo tempo que se confessa ou se enuncia antes da questão/pergunta - como se a sua vinda à ideia (e assim à filosofia !) e à palavra fosse indissociável de uma carta (lettre $)^{*}$ de amor... Indissociável do desvio por uma carta de amor ao próprio amor, tão trágica quanto ridícula, como no dizer de Fernando Pessoa o são sempre todas as cartas de amor ! Indissociável de uma carta em que o fogo do amor se pegasse às próprias palavras, às letras, às sílabas mesmo - para além dos apaixonados, só os pensadores-poetas e os filósofos-escritores terão talvez o génio de bem-fazer falar a língua para tentar fazer-lhe bem dizer o amor - à beira do silêncio, necessariamente, e na véspera da questão/pergunta que já configura como que um soluço do amor. Ou as suas cinzas. «Há aqui cinza», diz cada letra que tenta dizer o amor ao amor.

Eis, para começar, um exemplo de como o fogo ardente do amor se pega às palavras, às letras, às sílabas como um suspiro, doce e amargo, para tentar dizer-se, sublinhando ao mesmo tempo a relação difícil, de certa maneira talvez mesmo impossível, da língua ao amor ou do amor (que, quanto a ele, fala em línguas !) à língua - aqui, neste desvio da palavra que acolhe e diz ou tenta dizer o amor, que é como que o corpo verbal do amor, se anuncia talvez o seu

${ }^{1}$ Cf. Jacques Derrida, «Force et Signification» in L'Écriture et la Différence, (Paris: Seuil, 1967), 18.

* N.T.: De notar que, em francês, a palavra «lettre» tanto pode significar «carta» como «letra». 
primeiríssimo contratempo. Aquele que passa a tremer pela sua travessia da língua, pelo desvio das letras e das palavras para lograr dizer-se - sejam elas, como neste caso são, tocantes «palavras em brasa»! Palavras timbradas pelo paroxismo do próprio fogo do amor que tanto apela a dizer-se quanto à partida se sabe perdedor. É uma passagem de uma obra de Hélène Cixous onde nomeadamente a sílaba triliteral «jet» - escutável «je-te» e literalmente intraduzível para português -, para além de ritmar o batimento compulsivo de um pulso ou de um coração, tanto ritma o avesso de um grito silenciado como a provação de uma «derrelicção», de um ser-projectado a corpo perdido para outrem, de uma "Geworfenheit»" ${ }^{2}$, de um «être-jeté», onde sobretudo a ressonância franco-latina da questão filosófica de um «sujeito» (subjectile, sujeito, objecto, projecto, objecção e abjecção) simultaneamente à mercê do outro e da (sua) língua se dá a ouvir com o timbre vibrante e iluminado da genialidade:

«Nesta feira imensa como uma cidade de um dia tudo nos separa e tudo nos reúne. [Eu sublinho para realçar já aqui, quer o paradoxo de uma separação que separa unindo - sendo esta separação a lei paradoxal do amor -, quer o extra-ordinário, o élan extra-ordinário do amor no seio da própria comunidade ou do mundo e da luz, figuras da tercialidade aqui significada pela "feira imensa como uma cidade de um dia»]

O milagre ou a sorte lograda é que nós conseguimos, ainda assim, encontrar-nos e lançar palavras ardentes apesar de tudo. [...] É assim que na multidão imensa da exposição, arrebatada pela febre do amor, eu me encontro ao pé de ti num vagão de metro a abarrotar [...].

De repente, na paragem, a tua voz encostada a mim, como se fosse a minha, grita sem um som, no meu ser, adoro-te adoro-te adoro-te [je t'adore je t'adore je t'adore].

No barulho das máquinas e do mundo, as palavras são docemente gritadas, um pouco inquietas, é o presente de deus, e enquanto as portas automáticas me empurram para fora, grito também, porque não consigo pronunciar outra coisa. Então, cheia deste fogo e de pressa, eis que arrepio caminho para o meu quarto, onde tenho de me preparar a fim de te encontrar publicamente um pouco mais tarde. [...]

Nada me terá sido poupado. Mas, ainda assim, à noite pude reencontrar-te. E as tuas palavras ardentes estão na minha vida, adoro-te adoro-te ado ad' [je t'adore je t'adore jeta jet'] $\gg^{3}$ Eu sublinho.

2 Ph. Arjakovsky, F. Fédier, H. France-Lanord (dir.), Le Dictionnaire Martin Heidegger, (Paris : Cerf, 2013) 452-453.

3 «Dans cette foire immense comme une ville d'un jour tout nous sépare et tout nous réunit. Le miracle, ou la chance gagnée, c'est que nous arrivons à nous retrouver et à jeter les mots de feu malgré tout. [...] C'est ainsi que dans l'immense foule de l'exposition, emportée par la fièvre de l'amour, je me retrouve auprès de toi dans un wagon de métro bondé [...]. À l'arrêt, soudain, ta voix serrée à moi, comme si c'était la mienne, crie sans un son, dans mon être, je t'adore je t'adore je t'adore.

Dans le bruit des machines et du monde les mots sont hurlés doucement, un peu in- 
Para além do tremor da emoção ao rubro do amor, da hetero-auto-afecção do amor, o que pode significar este balbuciar à beira da afasia - adoro-te adoro-te ado ad' (lat. ad- para, aproximação)? Que quer dizer este dizer embargado - sem pontuação, repare-se! -, este ininterrupto suspiro quase sibilado onde manifestamente o muito e o muito pouco passam um no outro e se entrelaçam ? Esta expiração à beira do sufoco e do silêncio da amante para dizer o amor, para dizer o seu amor, para dizer o seu amor aо seu amor, que assina e assinala ela, no fundo, senão o primeiríssimo contratempo do amor ? $\mathrm{O}$ contratempo da sua vinda-a-partir à língua no rastro ciosamente melancólico da própria ex-apropriação desta pela amante ? O contratempo da indiscrição quase obscena da sua travessia sonhadora da língua, ela mesma apaixonadamente ex-apropriada pelo sujeito enamorado ? Como Jacques Derrida o diz - e tão bem, reparem! - nesta outra passagem de «Envois» onde está em questão a tragédia sem tragédia da destinação ${ }^{4}$ (quer dizer, para além da tragédia da impossibilidade do duo ou do par, da rectidão e da transparência da relação ao outro como outro em razão do desvio pela tercialidade figurada pela linguagem, a incerteza da própria recepção do envio que a ele e só ele é destinado, ou seja, a possível destinerrância do enviado) e assim da sua phila-telia, do seu amor, não da distância, mas «do timbre com ou sem amor timbrado» : escutemo-lo, atentando no problema filosófico que como que performativamente ele põe em cena - a saber, o problema da relação do amor à língua, que tenta dizê-lo, no eco da própria experiência de ex-apropriação «amante e desesperada da língua» ${ }^{5}$ pelo próprio «eu». E isto, porque neste registo do filosófico se pensa a vinda a si ou a experiência in-finita de não identidade a si do sujeito em relação ou por relação com a primazia da língua (do outro: do outro no sentido de vinda do outro, como o próprio outro, que

quiets, c'est le cadeau de dieu, et tandis que les portes automatiques me poussent dehors, je crie moi aussi, parce que je ne peux prononcer autre chose. Alors, pleine de ce feu et de hâte, me voilà qui rebrousse chemin vers ma chambre, où je dois me préparer afin de te retrouver publiquement un peu plus tard. [...]

Rien ne m'aura été épargné. Mais quand même la nuit j'ai pu te rejoindre. Et tes mots ardents sont dans ma vie, je t'adore je t'adore jeta jet'», Hélène Cixous, Rêve je te dis, (Paris: Galilée, 2003), 136-138.

4 «Voudrais ne m'adresser, tout droit, directement, sans courrier, qu'à toi mais je n'y arrive pas et c'est le fond du malheur. Une tragédie, mon amour, de la destination. Tout redevient carte postale, lisible pour l'autre, même s'il n'y comprend rien. [...] ça peut toujours t'arriver, à toi aussi, de n'y rien comprendre, et donc à moi, et donc ne pas arriver, je veux dire à destination. Je voudrais t'arriver, arriver jusqu'à toi, mon unique destinée, et je cours je cours et je tombe tout le temps, d'une foulée à l'autre, car il y aura eu, si tôt, bien avant nous», Jacques Derrida, «Envois» in La Carte Postale, de Socrate à Freud et au-delà, (Paris: Flammarion, 1987), 27-28.

5 «[...] aimante et désespérée de la langue», Jacques Derrida, Le Monolinguisme de l'Autre (Paris : Galilée, 1996) 59. 
não por ele possuída), que não a partir do sangue ou do solo - é o que Jacques Derrida designa por «circunsisão»: a saber, um estar marcado antes mesmo de falar, antes mesmo de poder falar, o que é válido tanto para homens como para mulheres, sendo este o recurso da desconstrução do falocentrismo e da diferença sexual pensada em termos de oposicção hierárquica :

«e quando eu te chamo meu amor, meu amor, é a ti que eu chamo ou ao meu amor? Tu, meu amor, és tu que assim eu nomeio, é a ti que eu me endereço? [...] quando te chamo meu amor, acaso te chamo, a ti, ou acaso te digo o meu amor? e quando te digo o meu amor acaso declaro o meu amor ou acaso te digo, a ti, meu amor, e que tu és o meu amor. Queria tanto dizer-te.» ${ }^{6}$

Ao amor - esta outra experiência impossivel e do impossivel ${ }^{7}$-, parece assim que é não somente preciso sonhá-lo, mas também sonhar dizê-lo. Sonhar bem dizê-lo, sonhando vencer o que Jacques Derrida chamará «o princípio postal $\rangle^{8}$. Quer dizer, o seu desvio em cada palavra e no seio de cada palavra, de cada letra, sempre assim, quanto ao amor, e um véu de casamento e um véu de luto. Dizendo o "princípio postal» quer a "adestinação» ${ }^{9}$ do envio ou do endereçamento, quer a indecidibilidade do próprio véu de palavras - um «princípio postal» que anuncia a própria aporia do amor, ao sugerir que aquilo que une ao mesmo tempo também separa. Exactamente como o «rastro» («trace») e o grafema em geral que, em sede desconstrutiva, têm sempre uma feição testamentária ${ }^{10}$ - estão já sempre in memoriam do que dizem ou referem.

6 « et quand je t'appelle mon amour, mon amour, est-ce toi que j'appelle ou mon amour? Toi, mon amour, est-ce toi que je nomme ainsi, à toi que je m'adresse? [...] quand je t'appelle mon amour, est-ce que je t'appelle, toi, ou est-ce que je te dis mon amour? et quand je te dis mon amour est-ce que je déclare mon amour ou bien est-ce que je te dis, toi, mon amour, et que tu es mon amour. Je voudrais tant te dire.», Jacques Derrida, «Envois» in op. cit., p. 12-13.

7 No âmbito da Desconstrução - que se pensa como uma certa experiência do impossível - o amor é (como a amizade, o luto, a morte, o sim, o dom, o perdão, a justiça, a democracia por vir, a paz, a hospitalidade, ...) impossível - um dos seus impossíveis, como tal apenas im-possível.

8 «Le désir de vaincre le principe postal: non pas pour te rapprocher enfin et t'emporter, l'emporter sur l'éloignement mais pour que me soit donné, par toi, l'éloignement qui me regarde.», J. Derrida, «Envois», op. cit., p. 32.

9 « [...] à l'intérieur de chaque signe déjà, de chaque marque ou de chaque trait, il y a l'éloignement, la poste, ce qu'il faut pour que ce soit lisible par un autre, une autre que toi ou moi, et tout est foutu d'avance, cartes sur table. La condition pour que ça arrive, c'est que ça finisse et même que ça commence par ne pas arriver. Voilà comment ça se lit, et ça s'écrit, la carte de l'adestination.», ibid., p. 34-35.

10 «Or l'espacement comme écriture est le devenir-absent et le devenir-inconscient du sujet. [...] Comme rapport du sujet à sa mort, ce devenir est la constitution même de la subjectivité. À tous les niveaux d'organisation de la vie, c'est-à-dire de l'economie de la mort. Tout graphème est d'essence testamentaire. Et l'absence originale du sujet de l'écriture est 
É o doce tormento do amor - o doce tormento da gaguez para dizer o amor. Não há pois amor feliz (Aragão dixit, Ferrat cantou)! Não há amor sem este tormento da (a)destinação, isto é, sem o temor e o tremor do seu endereçamento ao amado ou à amada na noite, que o mesmo é dizer, no desvio da mais doce e terna e jubilosa proximidade! Lembremos com Derrida que «desvio» [《écart»] é, em francês, o anagrama de «carta» [《carte»] e de «rastro» [«trace»] - tenhamos, pois, assim também presente que a letra/a palavra ou a carta que se endereça ao amor e tenta dizê-lo, confessá-lo ou testemunhá-lo, porta também já em si o desvio - desvia o amor $e$ do amor $e$ do amado ou da amada! Desvio que tanto testemunha a relação do amor à língua, a sua travessia da língua e a sua inscrição (ex-crição) na língua, quanto a relação do próprio sujeito à língua - que, insistimos, acontece ser sempre a língua do outro ${ }^{11}$-, tal como a relação da filosofia ao amor. No atraso da própria filosofia relativamente ao amor ecoa o atraso do próprio sujeito $e$ à língua $e$ a si mesmo e, no côncavo deste atraso, nasce o próprio élan do amor. A própria fome de amor e o ímpeto do amor para se dizer. Em suma, a palavra «amor», o mais simples «amo-te» porta pois já em si o luto do amor - não há palavra, por tocante que seja, que não esteja já in memoriam do amor de que é já sempre como que a sepultura verbal. Do amor se deveria dizer exactamente o mesmo que Derrida diz do poema (na sua diferença da poesia): a saber, que ele é

«um encantamento silencioso, a ferida áfona que de ti eu desejo aprender de cor» ${ }^{12}$.

Daí que, como se no princípio estivesse o sonho, o sonho do amor e o seu inevitável contratempo, eu não possa senão tentar aqui um discurso um pouco sonhador em torno do amor, muito mais do que um discurso sobre o amor - o que é já da minha parte um gesto de rendição diante do amor e uma maneira de sugerir, quer a singular impossibilidade e excepcionalidade do amor, quer a sua matinalidade ou originariedade - recordemos que, no dizer do Fedro, entre os gregos, o amor era quase tão antigo como o caos! E Maurice Blanchot lembrará também que a Afrodite clotiniana figurava ao mesmo tempo «o mar de onde nasce» ${ }^{13}$, «a noite que designa o sono perpétuo» e «a injunção silenciosa» da exposição à morte. $\mathrm{O}$ que parece querer dizer

aussi celle de la chose ou du référent.», J. Derrida, De la Grammatologie, (Paris: Seuil, 1967), 100.

11 Cf. J. Derrida, O Monolinguismo do Outro, trad. Fernanda Bernardo (Porto: Campo das Letras, 2001), 39.

12 «[...] une incantation silencieuse, la blessure aphone que de toi je désire apprendre par cœur.», J. Derrida, «Che cos'è la poesia ?» in Points de Suspension (Paris: Galilée, 1992), 307.

13 M. Blanchot, La Communauté Inavouable (Paris: Minuit, 1983), 77. 
que matinalidade, excepcionalidade e melancolia têm a mesma origem e a mesma data de nascimento. E é, de facto, a originariedade $e$ a incondicional soberania do amor, da Lei do amor em relação à filosofia, tal como a relação da filosofia $e$ ao amor $e$ a si mesma, que eu faço também questão de agora salientar aqui, uma vez que desde o seu nascimento a filosofia (cf. Fedro, 278d) se tem a si mesma pelo amor, pela amizade (philia) pela sabedoria (sophia). Está então aqui igualmente em questão, sublinhemo-lo também, uma dupla e mesma relação: a relação da filosofia $e$ ao amor $e$ a si mesma para pensar e dizer o amor - uma relação pela qual a filosofia não pode senão suspirar atrás do amor, atrás do sonho de pensar o amor dizendo-o, suspirando pela incurável melancolia do seu atraso face à excepcional matinalidade do amor : sero te amaui! "Sero te amaui, pulchritudo tam antiqua et tam noua, sero te amaui !» ${ }^{14}$, lamentava-se Santo Agostinho a respeito da beleza «tão antiga e tão nova» como o amor, no fundo : «bem tarde [oh beleza] eu te amei !» ${ }^{15}$ Pois bem, ousaria dizer que um gesto semelhante deveria também ser o da filosofia em relação ao amor - seria como que uma declaração de amor da filosofia ao próprio amor reconhecer o seu atraso ineliminável em relação à originariedade do amor: na língua de Agostinho, a filosofia poderia igualmente muito bem dizer: «bem tarde [oh amor] eu te amei!» De facto, tarde, tão tarde, bem tarde, muito, muitísso tarde vem sempre o tempo de amar: tu, «tu estavas comigo» e, eu, «eu não estava contigo.» ${ }^{16}$ [vamos já de caminho ver como é que este contratempo se inscreve nos amores de dois pares aforísticos do imaginário ocidental do amor como são Romeu e Julieta e Tristão e Isolda - tal como, finalmente, se inscreve em qualquer par, em não importa que par, de que estes dois são a encenação teatral!]

Como se o contratempo espreitasse, como espreita, logo no começo, a filosofia tem assim de comparecer diante da doce e intratável matinalidade do amor - de facto, o tempo do amor (este tempo que, segundo Derrida ${ }^{17}$, não vem senão a partir, a faltar, a faltar-nos, a dizer-nos adeus; este tempo de véspera e de vigília; este tempo de antes e de fora do tempo (do mundo)) está absolutamente acelerado em relação ao tempo da filosofia, em relação ao tempo do seu acolhimento pela filosofia que, atrasada em relação a ele, deve então comparecer diante da matinalidade e da velocidade curto-circuitada do tempo do amor. O que é também - nesta observação da relação da filosofia

14 «Tarde te amei, beleza tão antiga e tão nova tarde te amei !», S. Agostinho, Confissões, X, XXVII, 38, trad. Arnaldo do Espírito Santo et al. (Lisboa: INCM, 2000), 491.

15 Ibid., p. 491.

16 Ibid., p. 491.

17 Para o contratempo da filosofia e da religião (epinoia) no contexto da ocidentalidade, veja-se, nomeadamente J. Derrida, «Avances» in S. Margel, Le Tombeau du Dieu Artisan (Paris: Minuit, 1995), 24-34. 
a si mesma e ao amor, onde a anacronia do contratempo entra em cena e faz portanto parte da relação - o que é também, dizia, a minha maneira de, uma vez enunciado o problema da relação da língua e da filosofia ao amor, começar a colocar aqui em cena o idioma franco-alemão da eurofilosofia, que desejo saudar aqui, fazendo comparecer a filosofia diante do amor e diante dos seus outros no rastro, já não da já demasiado célebre coruja de Minerva de Hegel, mas antes no rastro de uma passagem de Minima Moralia de Th. Adorno. De facto, segundo Adorno e segundo Derrida a filosofia deve comparecer primeiramente diante do sonho, como se, observa Derrida, «o sonho fosse mais vigilante do que a vigília» ${ }^{18}$, do que o despertar e o acordar que, sabêmo-lo bem, de Platão a Husserl, define maioritariamente a essência da filosofia ligada, como ela está, ao imperativo racional da vigília, ao eu soberano, à omni-potência da consciência vigilante. Ora, perguntemo-nos : seria uma razão soberana acolhedora ao amor ? Seria ela capaz de bem pensar e de bem dizer o amor ? Um eu soberano apaixonar-se-ia ? Uma consciência vigilante deixar-se-ia morrer de amor(es)? O princípio de razão como princípio de cálculo entregar-se-ia ao amor?

Mas, segundo Adorno, a filosofia deveria comparecer e deveria responder não apenas diante do sonho, mas também diante da música - para Adorno representada por Schubert -, diante da poesia, diante do teatro e diante da literatura, para Adorno representada por Kafka. Quer dizer, assumindo o seu atraso, o seu irrecuperável atraso, a filosofia deveria comparecer diante destes outros que são para Adorno as artes - todas as artes : eis como ele o diz:

«Quando se acorda a meio de um sonho, mesmo do pior pesadelo, fica-se desiludido e tem-se a impressão de ficar frustrado da melhor parte. Mas os sonhos felizes, consolados, são na realidade tão raros como o é, segundo Schubert, a música alegre. Mesmo o mais belo sonho dos poetas porta, como que uma nódoa (wie ein Makel), a sua diferença em relação à realidade - a consciência de não nos facultar mais do que simples ilusões. Eis porque os sonhos mais belos têm como que uma fenda (wie beschädigt). Uma tal experiência está fixada de maneira desigual na descrição do teatro ao ar livre de Oklahoma em a América, de Kafka.» ${ }^{19}$

18 Cf. J. Derrida, Fichus (Paris: Galilée, 2002), 18 e 12-13.

19 «Lorsqu'on s'éveille au milieu d'un rêve, même du pire cauchemar, on est déçu et l'on a l'impression d'avoir été frustré de la meilleure part. Mais les rêves heureux, comblés, sont en réalité aussi rares que l'est, selon Schubert, la musique joyeuse. Même le rêve le plus beau porte comme une tâche (wie ein Makel) sa différence par rapport à la réalité, la conscience de ne nous procurer que de simples illusions. Voilà pourquoi les rêves les plus beaux ont comme une fêlure (wie beschädigt). Une telle expérience est fixée de façon inégale dans la description du théâtre de verdure d'Oklahoma dans l'Amérique, de Kafka.», Th. Adorno, Minima Moralia (Paris: Payot, 1991), 107. 
Então, se segundo Adorno a filosofia deve comparecer diante das artes, diante da arte das artes, como não teria ela de comparecer também diante do amor ? Diante da arte de amar ? Porque, não é o amor a arte das artes ? O poema dos poemas? O cântico dos cânticos? Não deveria então a filosofia comparecer igualmente diante do amor, tornando-se assim, quero dizer, assumindo assim a feição, não tanto do «amor pela sabedoria», mas o que um filósofo contemporâneo como Emmanuel Levinas chama «a sabedoria do amor» - a louca «sabedoria do amon», quer dizer, a sabedoria de um sujeito já sempre arqui-originariamente para-outrem na origem ou no fim do mundo ? Como a própria origem ${ }^{20}$ e o próprio fim $^{21}$ do mundo?

«A filosofia», diz Emmanuel Levinas em Autrement qu'être ou au-delà de l'essence, «é esta medida trazida ao infinito do ser-para-o-outro da proximidade, e como que a sabedoria do amor» ${ }^{22}$.

E assim, nesta condição ou, mais precisamente e no léxico do próprio Emmanuel Levinas, nesta incondição, «nós», o dito «sujeito», a ipseidade, o filósofo digno do nome, quer dizer, tão respeitoso quanto apaixonado pelo amor, seria ele mesmo amor ou, pelo menos, promessa de amor - isto, na audaciosa interpretação levinasiana do preceito bíblico : «ama o outro como a ti mesmo». Levinas rasura a comparação, narcisista, mercantilista e egocentrada, e defende que um tal amor és tu mesmo ! É a incondição da própria subjectividade de um sujeito individuado pela responsabilidade incondicional, infinita e hiperbólica para a responsabilidade incondicional, infinita e hiperbólica por outrém. Por um/a outro ou outra, mas também por todo e qualquer outro na sua dimensão humana. A ética da responsabilidade (ou do amor repensado em termos de responsabilidade) em sede levinasiana é um muito exigente, um muito difícil humanismo.

Mas isto é Levinas, Emmanuel Levinas, que exigentemente repensou a usura, a ambiguidade e a lisura do amor ${ }^{23}$ em termos de responsabilidade incondicional, hiperbólica e infinita - ou esta como o fundo repensado daquele. Não é no entanto a feição geral da filosofia ocidental que teve quase sempre uma má relação com o amor - que, mais precisamente, teve quase

20 Para esta questão, que tem implícita uma desconstrução da Fenomenologia, veja-se, nomeadamente, J. Derrida, Béliers (Paris: Galilée, 2003).

21 Para esta questão, cf., nomeadamente, J. Derrida, Chaque fois unique, la fin $d u$ monde (Paris: Galilée, 2003).

22 «La philosophie c'est cette mesure apportée à l'infini de l'être-pour-l'autre de la proximité et comme la sagesse de l'amour.», Emmanuel Levinas, Autrement qu'être ou au-delà de l'essence, (Dordrecht/Boston/London : Kluwer Academic Publishers, 1988), 205.

23 «L'amour est originaire [...] moi je l'emploie peu, le mot amour, c'est un mot usé et ambigu ; et puis il y a une sévérité : cet amour-là est commandé.», E. Levinas, «Philosophie, Justice et Amour» in Entre Nous (Paris: Grasset \& Fasquelle, 1991), 126. 
sempre um encontro falhado com o amor. Mesmo se o porta no seu nome, no próprio corpo do seu nome (philos + sophos), nunca, no entanto, a filosofia se abandonou à paixão do amor que, além do mais, sempre maltratou como o outro da razão ou do entendimento, que era preciso exconjurar. Pensemos, a título de exemplo, em Kant, que advogou a necessidade de domar as inclinações patológicas. Entenda-se: as paixões ${ }^{24}$. Em geral, no seu racionalismo, a filosofia esqueceu, maltratou e traiu o amor. Tal como dominantemente esqueceu e maltratou a diferença e a alteridade como tais. No entanto, e como Jean-Luc Nancy não se esquece de lembrar, «independentemente do que o seu lendário inventor tenha querido dizer, «filosofia» diz, apesar de tudo, isto : «amor do pensamento, amor pelo pensamento, porque o pensamento é amor. $\gg^{25}$ Eu sublinho: o pensamento, que não a filosofia, é amor.

Depois da enunciação da questão filosófica relativa à dificuldade de pensar e dizer o amor, e depois de referido o atraso irredutível e operativo da filosofia relativamente à matinalidade do amor, façamos agora uma pausa para um breve desvio - iremos aliás aqui de desvio em desvio... - com o intuito de testemunharmos, em grandes traços, necessariamente, este desencontro com o amor por parte da filosofia - um desencontro ou um esquecimento no entanto coexistente com a omnipresença da hybris do amor e da sua má reputação para a serenidade logocêntrica.

De facto, desde o Banquete de Platão ${ }^{26}$ - ou mesmo antes, mesmo antes de Platão, já em Heraclito e em Empédocles, em Pitágoras e em Parménides - que o esquema geral da filosofia relativamente ao amor está a operar, determinando, quer a filosofia, tal como ela se compreende a si mesma e se constrói, quer o amor, tal como nós o pré-compreendemos, o entendemos e eventualmente o vivemos. Se fosse necessário aventurar aqui este esquema numa fórmula, poder-se-ia tentá-lo nas palavras de $\mathrm{Nancy}^{27}$ e dizer com ele que o amor é o movimento extremo, para além de si, para além de um ser a cumprir-se, a realizar-se, a cumular-se.

De facto, a filosofia pensou sempre o amor como preenchimento de uma falta originária ( $O$ Banquete, 200 b-e), como cumulação completa e definitiva de uma falta. Lembrar-se-ão que, filho de Poros e de Penia, «da riqueza e da pobreza» (O Banquete, 203b-204b), Eros (já no esquecimento de Psyché, sublinhe-se !) é em Platão o "símbolo» da unidade perdida ( $O$ Banquete,

24 Kant, Fundamentação da Metafísica dos Costumes, tr. Paulo Quintela, (Lisboa: Ed. 70, 1995), 21 ss.

25 Jean-Luc Nancy, Une pensée finie, (Paris: Galilée, 1990), 228.

26 Cf. Léon Robin, Platon (Paris: Alcan, 1935), p. 70 ss; La Théorie Platonicienne de l'Amour, (I) (Paris : Alcan, 1933).

27 Cf. Jean-Luc Nancy, Une pensée finie, op. cit., p. 231. 
189d-191d), como se um só ser tivesse primeiramente sido, tivesse depois sido separado e, de seguida, procurasse a sua metade perdida, o seu sumbolon, quer dizer, o sinal do re-encontro e da conivência entre dois parceiros, ou o meio de reconhecimento entre duas partes ${ }^{28}$. Amar era assim desejar um bem absoluto tendendo à união, isto é, à apropriação (Lysis, 216d-220b) e, ipso facto, à realização. À cumulação. É também este o gesto omnipresente na filosofia ocidental em relação à alteridade em geral: a saber, o gesto de se apropriar dela, reduzindo-a a si no alvo do uno. Da unidade. E/ou da idealidade. Segundo o Timeu (37c), o círculo do Mesmo engloba e compreende o círculo do Outro. Levinas sublinha-o criticamente amiúde na sua obra, criticando o gesto predominantemente autonómico da ocidentalidade filosófica, onde todo o pensamento com sentido é tético - pensa à sua medida o que se posiciona e se enuncia teoricamente. Pensar é posicionar, hipostasiar, medir e apropriar, seja ele na modalidade light do com-preender ${ }^{29}$.

Tido pelo diálogo da generosidade de Platão, o Banquete leva pois a cabo, no seu gesto tão geral quanto dominante, um domínio do amor, ou, pelo menos, a pretensão de dizer uma verdade do amor que, no dizer de Nancy, "consigna a sua experiência, que hierarquiza as suas instâncias, substituindo ao seu alegre abandono a impaciência e o conatus do desejo.» ${ }^{30}$ No entanto, como nenhum outro, também o texto do Banquete não é de uma só peça, não fala a uma só voz e não é tecido de um só fio - a sua tecidura é também uma textura onde, sem violência, quero dizer, sem o fazer dizer de fora aquilo que ele não diz, ou não quer de todo dizer, para além do tratamento que aí é dado ao amor como falta, cumulação e apropriação, o texto do Banquete abre também o pensamento ao amor como acesso, como aproximação, como desejo impaciente e insaciável de inseparação absoluta, mais do que como um fim, abrindo também assim o pensamento à sua própria essência. Jean-Luc Nancy sublinha-o em «L'amour en éclats» - diz:

28 «Data, sem dúvida alguma, de época tão longínqua a existência do amor nos homens uns pelos outros, do amor que não só restabelece o nosso estado primitivo como de dois empreende fazer um só, curando assim a natureza humana.

Cada um de nós, portanto, não passa de uma téssera de homem, divididos, como estamos, em duas metades, à semelhança dos linguados, e é a sua própria metade, ou téssera, que cada um infatigavelmente procura.», Platão, O Banquete (191 d), tr. Maria Teresa Schiappa de Azevedo, (Lisboa: Verbo, 1973), 234.

29 «Si on pouvait posséder, saisir et connaître l'autre, il ne serait pas l'autre. Posséder, connaître, saisir sont des synonymes du pouvoir.», E. Levinas, Le Temps et l'Autre, (Paris: PUF, 1985), 83.

30 «[...] assigne son expérience, qui hiérarchise ses instances, tout en substituant à son abandon joyeux l'impatience et le conatus du désir.», J.-L. Nancy, Une Pensée Finie, op. cit., p. 230. 
No Banquete, «o Eros filósofo não se apresenta apenas com a maestria de uma doutrina triunfante, mas também numa penúria e num desfalecimento que deixam reconhecer a experiência do limite, onde o pensamento tem lugar. No Banquete, Platão toca os limites, e todo o seu pensamento se mostra aí numa retenção que nem sempre conhece novos lugares: toca no seu limite, quer dizer, na sua fonte, apaga-se diante do amor (ou no amor?) que reconhece como a sua verdade, pensa assim a sua própria nascença e o seu próprio apagamento, mas é desta maneira que ele pensa, remetendo ao amor, ao limite, a sua própria tarefa e a sua destinação. Aqui a filosofia está ocupada a recolher e a interpretar as experiências do amor, é no fim de contas o amor que acolhe e que desenrola a experiência do pensamento.

«Mas isto não aconteceu senão uma vez», sublinha Nancy, «na inauguração da filosofia, e mesmo esta vez isto não teve verdadeiramente lugar, não até ao fim.[...]

Assim, com Platão, o pensamento terá dito e terá falhado dizer que é amor - e o que isso quer dizer.

Não há uma filosofia que tenha escapado a esta dupla obrigação. O amor ocupa em cada uma um lugar ao mesmo tempo evidente e dissimulado (como, em Descartes, entre a teoria da união e a da admiração), ora envergonhada e decisiva (como, em Kant, na teoria da razão sublime), ou então essencial e subordinada (como, em Hegel, na teoria do Estado). Ao preço destas contradições e destes evitamentos, ele encontra de cada vez o lugar que não pode não ter, mas não o encontra senão a este preço.» ${ }^{31}$

31 «[...] l'Eros philosophe ne se présente pas seulement avec la maîtrise d'une doctrine triomphante, mais aussi dans un dénuement et dans une défaillance qui laissent reconnaître l'expérience de la limite, où la pensée a lieu. Dans le Banquet, Platon touche aux limites, et toute sa pensée s'y montre dans une retenue qu'elle ne connaît pas toujours ailleurs: elle touche à sa limite, c'est-à-dire à sa source, elle s'efface devant l'amour (ou dans l'amour?) qu'elle reconnaît comme sa vérité, elle pense ainsi sa propre naissance et son propre effacement, mais c'est de cette façon qu'elle pense, en remettant à l'amour, à la limite, sa tâche même et sa destination. Au lieu que la philosophie, ici, soit occupée à recueillir et à interpréter les expériences de l'amour, c'est en fin de compte l'amour qui accueille et qui déploie l'expérience de la pensée.

Mais cela n'a eu lieu qu'une fois, dans l'inauguration de la philosophie, et même cette fois cela n'a pas eu vraiment lieu, pas jusqu'au bout. [...]

Ainsi, avec Platon, la pensée aura dit et aura manqué de dire qu'elle est amour - et ce que ça veut dire.

Il n'y a pas une philosophie qui ait échappé à cette double contrainte. L'amour occupe dans chacune une place à la fois évidente et dissimulée (comme, chez Descartes, entre la théorie de l'union et celle de l'admiration), ou bien honteuse décisive (comme, chez Kant, dans la théorie de la raison sublime), ou bien essentielle et subordonnée (comme, chez Hegel, dans la théorie de l'État). Au prix de ces contradictions et de ces évitements, il trouve chaque fois la place qu'il ne peut pas ne pas avoir, mais il ne la trouve qu'à ce prix.», Ibid., p. 229-230. 
Daqui a nada, tocaremos talvez a fonte do preço destas contradições - a saber, o pharmakon da separação, ao mesmo tempo remédio e veneno, ao mesmo tempo condição de possibilidade e de impossibilidade (de im-possibilidade, pois) -, mas, de momento, gostaria ainda de sublinhar o quanto, à sua nascença e na sua veia homo-hegemonicamente autonómica e tética, a filosofia falhou ou faltou ao encontro do $\operatorname{amor}^{32}$ e esqueceu a paixão do amor - o amor sempre paixão, sempre pathos mesmo no seu élan mais desinteressado, como acontece no caso do amor-caridade ou do dom de si. Mas, se a filosofia faltou ao encontro do amor, se ela denegou ou silenciou ou pretendeu domar e apropriar a paixão do amor, o amor-paixão, esse, nunca deixou de estar já também sempre em cena - assim acontece, por exemplo:

- na Bíblia: e é de facto preciso ir, tão longe, até ela, porque neste mundo, que é o nosso, tudo é tradução de tradução do intraduzível. Desloquemo-nos, pois, até à Bíblia para lembrarmos «o amor absoluto», «o amor mais forte do que a morte» do sublime Poema dos Poemas ou Cântico dos Cânticos [amor que encontraremos dentro de instantes em cena em Tristão e Isolda e em Romeu e Julieta], bem como o não menos sublime Cântico de Amor da Primeira Carta de S. Paulo aos Coríntios, um dos textos fundadores do cristianismo, que, além do mais, canta a força da originariedade e da primazia do amor em relação à própria fé e à esperança.

No eco fervoroso ou no rasto melancólico do Cântico dos Cânticos, eis o canto do amor-doença/pathos forte como a morte - mais forte do que a morte:

«Durante as noites, no meu leito, procurei aquele que o meu coração ama; procurei-o, sem encontrá-lo

Vou levantar-me e percorrer a cidade, as ruas e as praças, em busca daquele que o meu coração ama ; procurei-o, sem encontrá-lo.

Os guardas encontraram-me quando faziam a sua ronda na cidade. «Vistes, acaso, aquele que o meu coração ama ? » $[\ldots]$

32 É a hipótese de Jean-Luc Nancy : «[...] l'amour est manqué par la philosophie, qui ne cesse pourtant de le désigner et de l'assigner. Peut-être ne peut-il être que manqué : ce qui expose, on ne saurait s'en emparer, ni le rejoindre. Si la pensée est amour, cela signifierait (pour autant que la pensée se confonde avec la philosophie) que la pensée manque sa propre essence - qu'elle manque par essence sa propre essence. Elle aurait donc dit, dans la philosophie (et dans la mystique, la poétique, etc.), tout ce qu'elle pouvait et tout ce qu'elle devait dire de l'amour - en le manquant, et en se manquant. Tout en aimant, et en aimant l'amour, elle l'aura manqué. C'est de là que le amare amabam de saint Augustin tire sa force exemplaire d'aveu.», Jean-Luc Nancy, «L'amour en éclats» in op. cit., p. 237-238. 
[Dizei-lhe que] estou doente de amor.

$$
[\ldots]
$$

Põe-me como um selo sobre o teu coração, como um selo sobre os teus braços ;

porque o amor é forte como a morte,

a paixão é violenta como cheol.

As suas centelhas são centelhas de fogo, uma chama divina.

As torrentes não poderiam extinguir o amor, nem os rios poderiam submergi-lo.»

(cap. V, vers. 3,$3 ; 5,8 ; 8,7$ )

E eis também ainda uma breve passagem do Cântico do Amor que pede aos homens para amarem, para serem eles mesmos amor, isto é, para se deixarem inspirar, hetero-afetar, que o mesmo é dizer, para carregarem o(a) outro(a)-amado(a) neles fora deles, o(a) outro(a) amado(a) ao mesmo tempo sempre mais antigo, mais alto e mais por vir do que eles, de que eles carreguem assim o luto como o luto de si próprios - eis então, dizia, a belíssima passagem do canto paulino do amor que poderão escutar, por exemplo, no coro de «Bleu», o filme da trilogia de K. Kieslowski («Trois Couleurs « Rouge », « Blanc » e «Bleu ») que deveríamos poder escutar aqui se tivessemos a sorte de ter tido as condições para isso:

«Ainda que eu fale as línguas dos homens e dos anjos,

se não tiver amor, sou como um bronze que soa

ou como um címbalo que retine.

Ainda que eu tenha o dom da profecia, e conheça todos os mistérios e toda a ciência,

ainda que eu tenha tão grande fé, que transporte montanhas, se não tiver amor, nada sou.

$$
[\ldots]
$$

Agora permanecem estas três coisas:

A fé, a esperança e o amor;

Mas a maior de todas é o amor.»

( $1^{a}$ Carta aos Coríntios, 13, 1-3; 14, 1-2)

- E a paixão do amor ou o amor sempre paixão, que se apossa do «eu»e o de-põe e ex-põe da sua egoidade soberana, já estava obviamente também em cena nos clássicos helénicos, nomeadamente em Sófocles, onde Eros é absolutamente invencível, irresistível - abate-se sobre os viventes como uma tempestade : «Sem combate, a divina Afrodite faz de nós o que quer», faz Sófocles dizer a Antígona, o mais sublime e aterrador exemplo de desobediência às leis da cidade (polis):

«Ó indomável Amor,

ó Amor que saltas sobre as tuas presas 
que vigias a noite dos ternos rostos de mulher e corres os oceanos e incendeias as paragens silvestres : nem um só imortal,

nem um só efémero conseguem fugir-te.

Transtornas totalmente quem se entrega a ti.

Até os justos tonas injustos e os arrastas para a ruína.

É obra tua esta guerra de consanguíneos :

triunfam os olhos radiosos da belíssima esposa

tão poderosos como as leis mais antigas e supremas.

Invencível, a deusa Afrodite move os destinos.» ${ }^{33}$

Antígona, a sublime insolente da mais alta manifestação do humano que, sabe-se, opondo ferozmente a lei do coração à do Estado, à da razão e à da razão do Estado, proclamará a divindade irresistível do amor, a sua omni-potência absoluta, que não tem lei. Que não conhece lei. O amor era o anomos por excelência, o fora-da-lei por excelência e, enquanto tal, deveria ser assim como que a Lei das leis - encontraremos o eco fervoroso desta tradição excessiva, subversiva do amor no amor «filho da Boémia» (cf. Habanera) da Carmen de Bizet, nomeadamente, que deveríamos também poder escutar aqui, por exemplo na soberba voz de Jessye Norman, e de que não lembrarei aqui senão o coro que anda em todos os corações e em todos os lábios :

«O amor é filho da boémia, /Ele nunca, nunca conheceu lei; / Se não me amas, eu amo-te, / Se te amo, toma cuidado contigo!» ${ }^{34}$

- E para salientar ainda a excepcionalidade da paixão do amor (e do amor sempre paixão!) na sua relação à lei, à razão e à razão de Estado, e para me limitar aqui a não mais do que a sugerir também o alcance singularmente hiper-político do amor, impossível me é não pensar também ainda aqui na citação de um provérbio russo de Maurice Blanchot segundo o qual «o beijo

33 Eis a versão francêsa na tradução de Ph. Lacoue-Labarthe: «Esprit de l'amour, toujours cependant vainqueur/Au combat ! Toi, Esprit de paix, qui t'assoupis/Sur l'industrie des hommes et sur les tendres joues/Des vierges dors tes nuits,/Et qui planes au-dessus des eaux/Et des maisons, dans le libre dehors. /Pour toi presque se brise/Le cœur des Immortels, et des hommes qui sombrent en sommeil./Et qui te touche ne s'appartient plus./[...] Car, sans combattre, elle/se joue de tout, la divine Beauté!/mais voici que moi-même je m'emporte/hors de la loi. Car à cette vue, je ne peux/plus retenir la source de mes larmes,/quand je vois marcher Antigone/à cette couche où tout vient à se taire.», Hölderlin, Antigone de Sophocle, tr. fr. de l'allemand Philippe Lacoue-Labarthe, (Paris: Christian Bourgois Éditeur, 1998), 99.

34 «L'amour est enfant de Bohême / Il n'a jamais connu de loi / Si tu ne m'aimes pas, je t'aime / Si je t'aime, prends garde à toi!», Bizet, «Havanaise» in Carmen (Jessye Norman/Seiji Ozawa, Philips/Radio France, 1988), 92. 
dos amantes destrói a sociedade» ${ }^{35}$ - uma citação que pode talvez escutar-se sob uma dupla ressonância (pelo menos) : primeiramente, no sentido em que o amor ou o duo amoroso, significado pelo «beijo dos amantes», «desconstrói» de facto a ordem de uma sociedade que se pretende apenas uma adição de singularidades. Em suma, uma multiplicidade ou uma pluralidade de indivíduos. Logo, no esquecimento da diferença e da heterogeneidade. Da excepcionalidade da heterogeneidade. Uma sociedade que não dá assim espaço à excepcionalidade da singularidade (singularidade que, note-se, não é o indivíduo uno, enquanto átomo ou eu soberano!).

De seguida, no sentido em que o duelo significado pelo «beijo dos amantes» abre a sociedade ou a comunidade que, ao mesmo tempo, interrompe e excede e heterogeniza : neste outro sentido a excepcionalidade da «insociável sociabilidade» a dois do «beijo dos amantes» seria paradoxalmente a condição de possibilidade da sociedade ou da «comunidade» ${ }^{36}$ enquanto «comunidade de singularidades». Este «beijo dos amantes», seja ele um beijo nos olhos, dar-nos-ia então a pensar a pluralidade ou a multiplicidade ou a universalidade a partir da excepcionalidade da interrupção e da heterogeneidade absolutas desenhadas pela própria tangência do tocar dos lábios ou dos olhos dos amantes - ou seja, dar-nos-ia a pensar a vinda à luz (phainesthai) do próprio dia. Numa palavra, dar-nos-ia a pensar o nascer do dia e/ou do mundo a partir de um retraimento da ordem do visível, das luzes, do espaçopúblico, da fenomenalidade do fenómeno. Em Le Toucher, Jean-Luc Nancy, Derrida di-lo assim:

"Quando olhos se cruzam intensamente, infinitamente, até ao abismo, até mergulhar Narciso no abismo, quando nada no mundo pode interpor-se, nem mesmo a luz, nem mesmo a fonte terceira de um sol, quando eu vejo o olhar amado que me olha para além de toda a reflexividade, porque não o amo senão na medida em que ele me vem do outro, é dia ou noite ?

$\mathrm{Se}$, como penso e assumo, como que para ganhar tempo (se ainda houvesse tempo para nós, tão depressa anulado quanto o espaço objectivo num tal visar.), não há dia nem noite possíveis senão a partir da possibilidade do olhar, e portanto do olhar trocado na abstinência e no perjúrio do tacto, dos olhos cruzados, como se diz, porque não se pode ver nada no mundo (tal é a origem e a possibilidade do mundo, que só um mundo pode também dar), sem a possibilidade, pelo menos, de uma superfície reflectora que faça ver, nem que seja a Narciso, outros olhos, sejam eles ainda os seus, então, no instante deste beijar dos olhos, pode perguntar-se se há já dia ou noite. $[\ldots]$

35 Maurice Blanchot, «Lettre 91 (10/5/83)» in Lettres à Vadim Kozovoï, (Paris: Éditions Manucius, 2009), 103.

36 «[...] l'étrangeté de ce qui ne saurait être commun est ce qui fonde cette communauté.», M. Blanchot, La Communauté Inavouable, (Paris : Minuit, 1983) 89. 
No beijar dos olhos, não é ainda dia, não é ainda noite. Noite alguma ainda, nem dia algum. Mas o dia e a noite prometem-se. Vou dar-tos, diz um ao outro. Ao romper do dia.» ${ }^{37}$

O que é, em suma, sugerir que o amor ou a relação amorosa é mais originária e mais excessiva do que qualquer lei do mundo - e que é em seu nome que se deve reclamar e proclamar o direito à contestação, à insubmissão, à resistência, à dissidência, à palavra, ... ou ao silêncio ou ao segredo (secernere, secretum). O que é dizer que, figurado pelo «beijo dos amantes», o amor é uma fonte de resistência à politização, mas, e como Derrida ensina, o que resiste à politização é também uma força de re-politização, de deslocamento do político.

- E ainda, e como que em eco a esta citação de Maurice Blanchot, ocorre-me ainda uma luminosa passagem de uma anotação dos «Carnets de Captivité» de Emmanuel Levinas que, a meu ver, vai justamente no mesmo sentido que a citação de M. Blanchot - é uma nota datada de 1942 onde o filósofo-prisioneiro, o filósofo então prisioneiro escreve : «O amor não é então uma escolha numa multiplicidade, é ele que torna a multiplicidade possível. Precede-a.» (Carnet 2) ${ }^{38}$. Quer dizer, o amor, o para-o-outro sem condição em Levinas, o puro movimento de amar, esta relação heteronómico-dissimétrica à alteridade ab-soluta do outro - relação «figurada» pelo «beijo dos amantes», em Blanchot, ou pelo «amor» ou por «Eros» no Levinas dos «Carnets de Captivité» (embora o pensamento do amor tenha uma dívida in-

37 «Quand des yeux se croisent intensément, infiniment, jusqu'à l'abîme, jusqu'à plonger Narcisse dans l'abîme, quand rien au monde ne peut s'interposer, et pas même la lumière, pas même la source tierce d'un soleil, quand je vois le regard aimé qui me regarde au-delà de toute réflexivité, car je ne l'aime que pour autant qu'il me vient de l'autre, est-ce le jour ou la nuit?

$\mathrm{Si}$, comme je le pense et l'assume, comme pour gagner du temps (s'il y avait encore du temps pour nous, aussi vite annulé que l'espace objectif en un tel baiser), il n'y a de jour et de nuit possibles que depuis la possibilité du regard et donc du regard échangé dans l'abstinence et le parjure du tact, des yeux croisés, comme on dit, car on ne peut rien voir dans le monde (c'est là l'origine et la possibilité du monde, que seul un monde peut donner aussi), sans la possibilité, au moins, d'une surface réfléchissante qui fasse voir, fût-ce à Narcisse, d'autres yeux, fussent-ils encore les siens, alors, dans l'instant de ce baiser des yeux, on peut se demander s'il y a déjà le jour ou la nuit.[...] Dans le baiser des yeux, il ne fait pas encore jour, il ne fait pas encore nuit. Point de nuit encore, et point de jour. Mais le jour et la nuit se promettent. Je m'en vais te les donner, dit l'un à l'autre. Au point du jour.», Jacques Derrida, Le Toucher, Jean-Luc Nancy, (Paris: Galilée, 2000), 343.

38 Calin, Rodolphe e Chalier, Catherine (dir.), Emmanuel Levinas, Euvres I, Carnets de Captivité et autres Inédits, (Paris : Grasset \& Fasquelle /IMEC Éditeur, 2009), 76. 
contornável para com Levinas ${ }^{39}$ ), pela «amância» ${ }^{40}$ em Derrida -, tem ainda um alcance singularmente político-democrático [um alcance, uma virtude ou, de acordo com o título (um pouco problemático a meu ver) deste atelier, um «uso»] : desenha a silhueta da condição de possibilidade do socius e do «ser-juntos-no-mundo». Dita e desenha a silhueta do «axioma» anti-neoteológico que, na Desconstrução, interdita defender que tudo é político e, ao mesmo tempo, que incita a abrir ou a respeitar incondicionalmente, em «política democrática», o que ultrapassa a ordem, a ordem da política ou da instituição em geral - a saber, e no dizer de J.-L. Nancy ${ }^{41}$ : «pensamentos», «artes», «amores», «paixões», «fés», «existências singulares», «justiça», etc. O que é dizer que o amor, enquanto relação ao outro como outro, quer dizer, salvaguardado ou respeitado no ab-soluto da sua alteridade ou da sua singularidade, desenha também o princípio trans-estático, trans-político para repensar, reinventar e redefinir diferentemente a "política» e a "democracia» (para além da polis, do demos e do kratos), porque, como diz Jacques Derrida em Politicas da Amizade:

«Não há democracia sem respeito pela singularidade ou pela alteridade irredutível, mas também não há democracia sem «comunidade de amigos» (koina ta phílōn), sem cálculo de maiorias, sem sujeitos identificáveis, estabilizáveis, representáveis e iguais entre si. Estas duas leis são irredutíveis uma à outra. Tragicamente inconciliáveis e para sempre feríveis. A própria ferida

39 Desde Le Temps et l'Autre (1947) e de De l'Existence à l'Existant (1947) - onde, na sua dualidade inultrapassável, Eros é relação com o mistério da alteridade absoluta, à época significada pelo feminino, e já uma ruptura seja com a unidade do ser, proclamada por Parménides, seja com o amor falta-e-fusão em Platão - a Totalité et Infinie (1961) onde, na dita «fenomenologia do amor», o amor não se transcende (na fecundidade, na filialidade e na fraternidade) sem equívoco - e a Autrement qu'être ou au-delà de l'essence (1974) - onde, no seu registo meta-ontológico, a filosofia é ela mesma redefinida como «sabedoria do amor» -, toda a investigação filosófica sobre o amor tem uma dívida evidente para com Emmanuel Levinas.

40 «[...] é a isto que eu estaria tentado a chamar a amância [aimance] : o amor $n a$ amizade, a amância para além do amor e da amizade segundo as suas figuras determinadas, [...] O que não quer dizer que esta amância possa produzir-se, ela mesma, sem figura : por exemplo, a phília dita grega, o amor cortês, esta ou aquela grande corrente, como se diz, da mística. Mas uma amância atravessa estas figuras.» Jacques Derrida, Políticas da Amizade, tr. Fernanda Bernardo, (Porto: Campo das Letras, 2003), 81.

41 «La politique démocratique est donc politique en retrait d'assomption. Elle coupe court à toute espèce de "théologie politique", qu'elle soit théocratique ou sécularisée. Elle pose donc en axiome que ni tout (ni le tout) n'est politique. Que tout (ou le tout) est multiple, singulier-pluriel, inscription en éclats finis d'un infini en acte ("arts", "pensées", "amours", "gestes", "passions" peuvent être certains noms de ces éclats.», J.-L. Nancy, Vérité de la Démocratie, Paris: Galilée, 2008, p. 60. 
se abre com a necessidade de ter de contar os amigos, de ter de contar os outros, na economia dos seus, ali onde o absolutamente outro é absolutamente (qualquer) outro [tout autre est tout autre].» ${ }^{42}$

Termino aqui, algo abruptamente, o meu sonho de tentar dizer o amor, oblíqua e sucintamente referidas que foram também as questões filosóficas que lhe são inerentes, e passo agora a palavra ao «sonho de amor» de um outro (Wagner) que, como verão, parece dar razão tanto a Adorno como a Derrida, filósofos para quem, relembro, o sonho está no princípio, mas para quem também «mesmo o mais belo dos sonhos porta como que uma nódoa». Quer dizer, mesmo os mais belos sonhos do que quer que seja estão já feridos, maculados, estragados. São sonhos! Sonhos que têm de desenhar-se nos hieróglifos das palavras. Mas veremos também que somos do estofo dos nossos sonhos, e que o sonho não é finalmente senão o próprio espelho da alma, de psyché (a outra de Eros!), o nome comum da alma, já sempre dividida, já sempre em si separada de si, independentemente do seu querer.

Será também agora o momento de aproximar a sublimidade deste «sonho de amor» de Wagner na figura de dois pares aforísticos que, no imaginário ocidental do amor, por excelência simbolizam o amor absoluto : Romeu e Julieta e Tristão e Isolda. E será também o momento de sublinhar neste teatro do «amor absoluto», tal como no mais simples e universal «mal de amar» do mais comum dos mortais, a paradoxal condição de possibilidade do amor, mostrando como a aliança, como o véu branco-negro do traço de união do par enamorado se revela, ao mesmo tempo, um traço de separação sem reparação possível. Exactamente como o véu da palavra, significado ou figurado pelo corpo verbal, que começámos por evocar e lembrar. Será, em suma, o momento de aproximarmos a cena do contratempo na sublime e incontornável melancolia do amor plasmada em alguns dos seus mais admiráveis monumentos-testemunhos - aqui os de Romeu e Julieta e de Tristão e Isolda.

42 Jacques Derrida, Políticas da Amizade, op. cit., 36. 


\title{
§ 2. Monumentos ao amor - Melancolias do mais belo de todos os sonhos
}

\author{
«L'amour n'est qu’une série de cicatrices. \\ “Nul cour n'est aussi entier qu'un cœur brisé”"» \\ Élie Wiesel, Le Cinquième Fils
}

«le plus grand amour naît de la plus grande force de dissociation »

J. Derrida, «Aphorisme à contretemps»

«Como, no fundo, na minha vida nunca conheci a verdadeira felicidade do amor, quero erguer a este mais belo de todos os sonhos um monumento (ein Denkmal), onde, do princípio ao fim, ele poderá assim encontrar um saciamento. Tenho em mente o esboço de um Tristão e Isolda: a mais simples mas também a mais ardente das concepções. Depois, quero enrolar-me na vela negra que esvoaça rumo ao desenlace e morrer.» ${ }^{43} \mathrm{Eu}$ sublinho

É Wagner, é Richard Wagner que, nesta carta de 16 de Dezembro de 1854 endereçada a Franz Liszt, sonha elevar ao mais belo de todos os sonhos, ao amor, um monumento (ein Denkmal) - Wagner, «o maior melancólico que nos deu a música» ${ }^{44}$ no dizer de Nietzsche corroborado por Boulez ${ }^{45}$, sonha com o amor e pensa na morte. Sonha com o amor pensando ao mesmo tempo na morte - na «vela negra» que, qual sudário, na sua morrência, no seu moriendo ${ }^{46}$ o envolverá. Mas, antes de morrer, diz querer erguer a este sonho, na verdade ao «mais belo de todos os sonhos», um monumento. Tristão e Isolda (1865), «a mais simples mas também a mais ardente» das histórias de

43 «Da ich nun doch im Leben nie das eigentliche Glück der Liebe kennengelernt habe, will ich diesem schonsten aller Träume ein Denkmal setzen, an dem sie sich von Anfang bis Endes so recht sättigen soll. Ich habe im Kopf einen Tristan und Isolde entworfen: die einfachste aber vollblutigste Konzeption. Mit der schwarzen Flagge, die am Ende weht, will ich mich dann zudecken und sterben.», Richard Wagner in: Richard Wagner, Franz Liszt, Briefwechsel zwischen Wagner und Liszt, (Leipzig: Breitkopf und Härtel, 1900), 84 [Correspondance, trad. J. Lacant e al., (Paris: Gallimard, 1975), 72].

44 Friedrich Nietzsche, «Le Cas Wagner» in: Euvres Philosophiques Complètes, Tome VIII - 1, (Paris : Gallimard, 1974), 35. E em Nietzsche contre Wagner («Là où je trouve à redire) in $O C$, VIII, p. 349 reitera: «Ma mélancolie entend trouver le repos dans les réduits et les abîmes de la perfection: c'est pour cela que j'ai besoin de musique. Mais Wagner rend malade».

45 Pierre Boulez, Points de Repère (Paris: Bourgois, 1981), 199-273 ; Jalons (pour une décennie), (Paris : Bourgois, 1989), 326.

46 Como nomeadamente M. Blanchot o refere, moriendo não é acabar - é antes não acabar de acabar. Ou, como J.-L. Nancy o refere, é ir «infinitizando», cf. Jean-Luc Nancy, À l'Écoute, op. cit., p. 52, nota 1. 
amor, é esse monumento - um monumento de alegria sublime e de jubilosa melancolia para um sonho de amor: a menos que seja um monumento para o amor como sonho! Como o sonho daquele que confessa não ter nunca conhecido, na sua vida, a verdadeira felicidade do amor, confessando assim um luto demasiado absoluto do amor. Tristão e Isolda é o poema musical deste luto sublime - uma «volúpia celestial» ${ }^{47}$ que, no dizer de Nietzsche - wagneriano assumido desde o primeiro compasso de Tristão e Isolda - mingua e empobrece o mundo de quem não teve a sorte de escutá-lo.

Mas, perguntemo-nos: o que é o sonho e o que é a «realidade»? Aquilo a que se chama «realidade»? Como Shakespeare, que antecipadamente nos conheceu a todos, à nossa pobre incondição humana, e que em The Tempest (1623) faz dizer a Próspero que a vida não é senão um sonho de cuja matéria somos feitos - «A matéria que nos compõe/ É igual à dos sonhos; e a nossa curta vida/ Cercada por um sono» ${ }^{48}-$, como Shakespeare, pois, Wagner parece também pensar que a vida não é senão um sonho, e que entre o sonho e a realidade não há senão um véu - o ténue ecrã de um véu: um véu musical, nele - Wagner -, um véu de palavras em Shakespeare - o escritor -, tal como no pensador-filósofo ${ }^{49}$ e no poeta: a sua obra e a sua re-nascença (que, se-

47 «Para tudo confessar, a juventude não me teria sido suportável sem a múscia wagneriana. [...] Quando prtendemos libertar-nos de uma opressão intolerável, tomamos haschich. Pois bem: eu tomei Wagner. [...] A partir do momento em que houve uma partitura de Tristão para piano [...] tornei-me wagneriano. [...] Hoje, procure em vão em todas as artes uma obra que iguale Tristão na sedução fascinante, na espantosa e suave infinitude. Todas as estranhas criações de Leonardo de Vinci perdem o encanto mal se ouvem os primeiros compassos de Tristão. Esta obra é incontestavelmente o nec plus ultra de Wagner [...] O mundo é estreito para aquele que nunca esteve bastante doente para poder apreciar esta volúpia celeste! [...] considero Wagner o maior benfeitor da minha vida. Uniu-nos o termos sofrido os dois profundamente», F. Nietzsche, «Porque sou tão sagaz» in Ecce Homo, op. cit., p. 62-63.

48 «We are such a stuff / As dreams are made on, and our little life / Is rounded with a sleep.», William Shakespeare, «The Tempest» in The Complete Works of William Shakespeare [IV, 1. 1157-8], (London: Abbey Library, 1977), 25 [em português, A Tempestade, trad. Fátima Vieira, (Porto: Campo das Letras, 2001), 109].

$49 \mathrm{Em}$ «Un ver à soie», J. Derrida lembra-nos também a voz de um outro alemão, Walter Benjamin, para quem pensar era colocar véus/velas («Denken heisst [...]. Segel setzen). Recordo-o aqui, assim recordando uma vez mais o diálogo filosófico franco-alemão que aqui saudamos: «Il s'agit, pour le dialecticien, d'avoir le vent de l'histoire universelle dans les voiles (den Wind der Weltgeschichte in den Segeln zu haben). Penser signifie chez lui mettre les voiles. (Denken heisst bei him: Segel setzen). La façon dont elles sont mises, voilà ce qui est important. Les mots sont ses voiles (Worte sind seine Segel, à moins qu'on ne traduise ainsi : ses voiles (ne) sont (que) des mots). La façon dont ils sont mis les transforme en concepts. [...] Être dialecticien signifie avoir le vent de l'histoire dans les voiles. Les voiles sont les concepts (Die Segel sind die Begriffe). Mais il ne suffit pas de disposer de voiles (über die Segel zu verfüfen). Ce qui est décisif, c'est l'art de savoir 
gundo Freud, dura toda a vida) ou o seu ser-para-a-morte. "Aschenglorie: [...] grub ich mich in dich und in dich». O próprio amor, dirá Derrida no eco do verso sublime de Paul Celan ${ }^{50}$ :

«O amor fazia-se fazer amor [...] como se fosse necessário embrulhar-se na sua própria mortalha, na mortalha branca da sua própria pele, para ficar junto a si, para permanecer o ser que tinha sido em vista de se reengendrar a si-mesmo» ${ }^{51}$

É em «Un ver à soie», numa passagem sonhadora onde o filósofo observa como a cada passo renascemos, tornando-nos aquilo que somos por meio da nossa assinatura, melhor, da nossa contrassinatura da língua (do outro), que nos precede, plasmada numa obra que configura a «monumentalização» ${ }^{52} e$ de nós mesmos, do que nos sonhamos ser, $e$ do nosso nome - uma obra por isso sempre autobiográfica ${ }^{53} \mathrm{ou}$, mais precisamente, auto-bio-tanato-hetero-gráfica na qual nos embrulhamos morrendo. Vivendo a morrer, como, no fundo, a cada passo vivemos sempre saudando intensamente, vibrantemente a vida...

Tristão e Isolda é então o exemplo sublime de um monumento auto-bio-tanato-hetero-gráfico ao amor. Um eco, um monumento que, notemo-lo, no

les mettre (die Kunst, sie setzen zu können).», W. Benjamin, Das Passagen - Werk, tr. fr. J. Lacoste, Paris Capitale du XIX siècle. Le livre des Passages, (Le Cerf, 1989), 491. Citado por J. Derrida em «Un Ver à soie» in: Hélène Cixous, Jacques Derrida, Voiles, (Paris: Galilée, 1998), 80-81 [«Um bicho-da-seda de si» in : Hélène Cixous, Jacques Derrida, Véus ...à Vela, tr. Fernanda Bernardo, (Coimbra, Quarteto, 2001), 73].

50 «GRAND LARGUE / aborde, toi la nuit / la voile de secours / se gonfle, // Dans l'écrin / à bord / est inséré ton cri, / tu étais là, tu es en bas. // tu es en dessous, // je pars, je pars avec les doigts / de moi, / pour te voir, avec les doigts, toi la D'en dessous» - «VON QUERAB / komm ein, als die Nacht, /das Notsegel / bauscht sich, // eingeschreint / an Bord / ist dein Schrei, / du warst da, du bist unten, // uterhalb bist du, // ich geh, ich geh mit den Fingern / von mir, / dich zu sehn, /mit den Fingern, du Untre», Paul Celan, Partie de Neige / Schneepart, (Paris : Seuil, 2007), 32-33.

51 «L'amour se fais[ant] faire l'amour [...] comme s'il [...] fallait s'envelopper dans son propre linceul, le linceul blanc de sa propre peau, pour rester auprès de soi, l'être qu'il avait été en vue de se réengendrer soi-même», Derrida, «Un ver à soie» in J. Derrida, H. Cixous, Voiles (Paris : Galilée, 1998) p. 84. [«Um bicho-da-seda de si» in: Hélène Cixous, Jacques Derrida, Véus...à Vela, tr. Fernanda Bernardo (Coimbra: Quarteto, 2001), 76].

52 Para a questão da monumentalização do nome próprio, cf. J. Derrida, Signéponge, (Paris : Seuil, 1988).

53 Autobiográfica, não no sentido de um «eu» que escreve sobre si próprio, mas que se escreve, como bem observa Pontalis: «J'y tiens tant à cette différence entre écrire sur soi e t s'écrire que j'ai avance, ici et là, le terme d'autographie. L'autographie n'est pas un genre littéraire comme le jornal intime, les Mémoires, l'autobiographie, l'autoportrait. À mes yeux elle est à la fois la source et la finalité de l'acte d'écrire.», J.-B. Pontalis, En Marge des Nuits, (Paris : Gallimard/folio, 2010), 67. 
idioma de Wagner (Denkmal) guarda uma referência mais explícita à memória, quer dizer, ao pensamento que recorda, que rememora, que já está, que já está sempre in memoriam - daí também a proximidade de um tal Denkmal a um Túmulo: da mesma maneira que, como sugeri antes, a palavra (ao mesmo tempo glória e cinzas) não passa já de uma sepultura verbal para o que nomeia (uma vez que está já sempre em memória do seu próprio dizer ou do referente que salva-guarda), existem mesmo poemas chamados Túmulos (Tombeaux) - os de Mallarmé por exemplo: «Calme bloc ici-bas chu d'un désastre obscur...». E ainda: «Le temple enseveli divulgue par la bouchel Sépulcrale». Poemas intitulados túmulos que enfaticamente nos lembram que um poema é já sempre um túmulo, tal como a palavra, a obra e o véu (velum que tanto talha o desvio como o luto) na sua condição de nomes da escrita: escrever é tecer véus. Ou velas. Ou asas.

Não há assim obra que não seja um túmulo. Um glorioso túmulo de cinzas. Aschenglorie. E no entanto, salienta Derrida, estes poemas-túmulos não têm apenas como fim prometer a imortalização "ao morto doravante para sempre no túmulo», ao morto desta «morte simbólica». Não, refere o filósofo: não são obras destinadas «a descrever ou a analisar o túmulo existente». São antes obras destinadas «a institui-lo por um acto de linguagem, a guardar, a honrar, a bendizer, a cantar uma memória prometendo-lhe um domicílio verbal mais resistente do que a pedra» ${ }^{54}$. Eu sublinho.

Túmulo seria então o próprio poema, o poema musical no caso de Wagner - o próprio poema musical que se encontra no lugar do luto do amor, quando é preciso o luto. Luto que é ainda o mais vivo testemunho do amor. Do amor vivo - a viver-se -, e não apenas do amor perdido. E o luto: quando é ele, de facto, preciso? Pois bem, sempre! Desde sempre - o luto é originário. O chamado «trabalho do luto» (de si, do outro, da língua, do amor, etc.) começa na véspera de tudo: do poema, do canto, da obra, do eu, da palavra, do rastro... Como o seu eco - o eco «das universalia ante rem» ${ }^{55}$, como Nietzsche diz ser a música. O luto é originário, ou mesmo pré-originário ${ }^{56}$ - o outro e a língua do outro (no sentido de vinda do outro) estão já sempre

54 «[...] à l'instituer par un acte de langage, à garder, honorer, bénir, chanter une mémoire en lui promettant une demeure verbale plus résistante que la pierre», Jacques Derrida, «Avances» in: Serge Margel, Le Tombeau du Dieu Artisan, (Paris: Minuit, 1995), 15.

55 F. Niezsche, O Nascimento da Tragédia, tr. Helga Quadrado (Lisboa: Relógio d'Água, 1997), 149.

56 «Nous le savons, nous le savions, nous nous souvenons, avant la mort de l'aimé, que l'être-en-moi ou l'être-en-nous se constitue depuis la possibilité du deuil. Nous ne sommes nous-mêmes que depuis ce savoir plus vieux que nous-mêmes, et c'est pourquoi je dis que nous commençons par nous en souvenir, nous arrivons à nous-mêmes par cette mémoire du deuil possible.», Jacques Derrida, «Mnemosyne» in : Mémoires, pour Paul de Man, (Paris: Galilée, 1988), p. 53. 
aí, quando um «eu» e o amor chegam... Onde e quando há relação ao outro como outro - nem que seja na relação a si-próprio como outro - há luto. Sempre, portanto! Daí que o rastro, tal como o grafema em geral, seja sempre testamentário. É sempre um véu de luto - é sempre um monumento em memória, tal como a filosofia está já sempre em memória do amor que diz e de que diz o ser: eis, diz J. Derrida, «o que nos dá a pensar a experiência do luto - que começa no "primeiro" traço, quer dizer, antes da percepção, na véspera do sentido» ${ }^{57}$. Na véspera de tudo! Na véspera de tudo e como condição de (possibilidade de) tudo.

Então, quando se sonha com o amor e com a morte, como Wagner - e para continuar a manter-me ainda aqui no registo franco-alemão da cultura europeia -, e quando se sonha erguer um monumento a este belo sonho mortal, como não recordar Tristão e Isolda? Tristão e Isolda que, com Romeu e Julieta, são por excelência no imaginário ocidental do amor as figuras do amor absoluto: para nada aqui dizer também dessas outras admiráveis figuras do amor-paixão que são Maria-Madalena ${ }^{58}$, Ariadne, Cornélia e Ofélia, sem esquecer também a portuguesa Mariana Alcoforado ${ }^{59}$ de quem tão

57 «[...] ce que nous donne à penser l'expérience du deuil - qui commence à la "première" trace, c'est-à-dire avant la perception, à la veille du sens.», Ibid, p. 51.

58 Veja-se, Rainer Maria Rilke, L'Amour de Madeleine / Die Liebe der Magdalena (Paris: Arfuyen, 2000).

59 Em 1669 foi publicado em Paris (por Claude Barbin) um pequeno livro intitulado Lettres Portugaises traduites en françois - não era feita qualquer referência nem ao nome do autor(a) nem ao do seu tradutor ou da sua tradutora. Mas, da leitura das Cartas e de uma advertência «ao leitor» na primeira página do pequeno livro, podem saber-se pelo menos três coisas. A primeira, que as cinco Cartas traduzidas para francês tinham sido escritas por uma religiosa portuguesa chamada Mariana. A segunda, que as Cartas se endereçavam ao seu amante francês, um «Gentilhomme de qualité, qui servoit en Portugal», mas de nome desconhecido. A terceira, que a edição e a tradução das Cartas a partir de um original perdido, por um tradutor igualmente desconhecido, se endereçavam ao prazer «de tous ceux qui se connoissent en sentiments, ou les loüer, ou les chercher avec tant d'empressement».

O segredo e o perfume de escândalo que envolviam o pequeno livro, onde uma jovem mulher e, ademais, uma jovem mulher freira deixava falar aberta e livremente o seu coração apaixonado bem para além do decoro (da época), prometia-o de antemão a uma grande fortuna - promessa que o destino não desmentiu. As Lettres portugaises foram uma sensação no mundo literário desde a sua publicação, en 1669, tendo conhecido inclusive cinco edições durante o primeiro ano.

Será, justamente, ao longo das convulsões da fortuna deste raro pequeno livro que uma parte do segredo que o envolvia será levemente desvendado. De facto, o nome do destinatário das Cartas será posto a nu no próprio ano da sua edição, no prefácio de uma contrafacção do livro publicado (por Pierre du Morteau), em Colónia, sob o título Lettres d'amour d'une religieuse portugaise: o «Gentilhomme de qualité» seria Monsieur Le 
Chevalier de Chamilly (1635-1715), conde de Saint-Léger, oficial que lutara em Portugal, onde teria chegado em 1665, sob as ordens de Frederico de Schomberg, durante a Guerra da Restauração da independência (1663-1668) - o que haveria de vir a ser confirmado por Saint Simon e por Duclos. E Lavergne de Guilleragues, secretário do gabinete de Louis XIV, poeta, amigo de Racine e director da Gazette de France, seria o tradutor das Cartas, de que o original português fora perdido - hoje em dia, uma larga maioria de especialistas sustenta que Guilleragues é o próprio autor das Lettres Portugaises. Numa querela certamente sem fim, outros continuam, no entanto, a interrogar-se sobre as razões pelas quais As Cartas guardam, apesar de tudo, traços da sintaxe portuguesa. Além disso, o arquivo histórico atesta também que na biblioteca dos Alcoforado foram encontrados muitos livros em francês - um sinal provável da sua utililização da língua francesa.

O nome da autora das Cartas, esse, permanecerá no silêncio até 1810. De facto, este nome, que Stendhal tem pelo próprio paradigma do amor-paixão («Il faut aimer comme la religieuse portugaise, et avec cette âme de feu dont elle nous a laissé une si vive empreinte dans ses Lettres immortelles»), não se tornará conhecido senão em 1810. E pela mão de Boissonade que confessará, no «Journal de L'Empire», ter um exemplar das Lettres Portugaises da edição de 1669 em que, escrito à mão, e com caligrafia da época, haveria a seguinte nota: «La religieuse qui a écrit ces Lettres s'appelle Mariana Alcoforado, religieuse de Beja, entre l'Estremadura et l'Andalusia.»

Começará assim o mito da religiosa portuguesa, Soror Mariana Alcoforado (Beja, 2 de Abril de 1640-28 de Julho de 1723) que, tendo entrado e vivivo no Convento de Nossa Senhora da Conceição, na vila de Beja, é apontada como autora das cinco Cartas Portuguesas endereçadas a Noel Bouton de Chamilly.

Da existência de Mariana Mendes da Costa Alcoforado, bem como da história da sua paixão amorosa por Chamilly, ninguém dúvida: destinada, já desde o testamento da mãe, a vir a ser freira, não teria sequer onze anos quando, sob soberana decisão do pai, se viu obrigada a entrar, em 2 de Janeiro de 1650, sem traços de qualquer vocação religiosa, para o Real Mosteiro de Nossa Senhora da Conceição, em Beja - Mosteiro do qual ela se tornará um dia abadessa e onde, idosa, morreu. A sua relação com o marquês de Charmilly, que ela terá visto pela primeira vez do terraço do convento [«o terraço de onde se avistava Mértola», Carta V], de onde assistia às manobras do exército, e que relata na Carta $I V$, data talvez dos anos 1667-1668. Pertencendo Mariana à toda-poderosa família dos Alcoforado, o escândalo desta paixão desencadeou a cólera da família (Carta IV e V) e terá feito a «manchete» da época. Chamilly escapa-se: regressa a França «com falsos pretextos», acusará a Carta III, na promessa de voltar, um dia, para procurar Mariana. As Cartas Portuguesas são ditadas pela paixão desta separação - pela paixão amorosa à prova desta separação: «A crueldade da tua ausência, talvez eterna, em nada diminui a exaltação do meu amor. Quero que toda a gente o saiba, não faça disso nenhum segredo : estou encantada por ter feito tudo quanto fiz por ti, contra toda a espécie de conveniências. E já que comecei, a minha honra e a minha religião hão-de consistir só em amar-te perdidamente toda a vida», Carta II.

Datadas de Dezembro de 1667 a Junho de 1668, as cinco Cartas, apaixonadas e líricas, confessam, numa franqueza absoluta e numa ternura refinada e tocante, o seu amor e, finamente, a desolação e o «desespero mortal» do seu abandono (Cartas IV e V). Da tortura da separação à fé no reencontro, da dúvida do amor do amante ao mais sombrio 
desespero da traição e do abandono, estas cinco Cartas são a grafia «da amargura que acompanha um amor violento quando não é correspondido» (Carta, V).

No entanto, já mais de uma voz se levantou para contestar a veracidade deste mito chamado «la religieuse portugaise». Mais de uma estima que a pobre religiosa apaixonada e abandonada de Beja não pode ser a autora das Cartas Portuguesas. A controvérsia em torno do autor(a) das Cartas prolonga-se até aos nossos dias. Estimando estas Cartas demasiado belas para serem escritas por uma mão de mulher, Rousseau, por exemplo, negará a sua autenticidade. Um ponto de vista que será igualmente partilhado pelos escritores portugueses Alexandre Herculano e Camilo Castelo Branco. Talvez mesmo, nos nossos tempos, pelo próprio poeta Eugénio de Andrade - que declara contudo não ter tomado nenhum partido na querela em torno do autor(a) das Lettres (Cartas Portuguesas, atribuidas a Mariana Alcoforado, trad. Eugénio Andrade, (Porto: Limiar, 1977), 14) -, a crer na indecibilidade da nota-prefácio da sua tradução, onde, numa página onde dá conta do espírito que guiou a sua tradução, se pode ler : «Procurámos, isso sim, ser fiel ao original, aguentar-lhe o ritmo largo e por vezes descosido, e, ainda, não perder de vista a simpicidade com que uma mulher poderia escrever ao homem que ama, se realmente o ama e escreve só para ele. Mas esta última intenção foi o nosso pior inimigo, pois o texto, com uma frequência maior do que seria desejável, negava-se a tal, impondo-nos um estilo afectado, de um artifício difícil de conciliar com a magnífica música de um corpo exasperado de desejo e abandono, que tanta vez rompia, sem se fazer anunciar. Quem falava nas «Cartas» estava mais próximo de qualquer dama cuja educação tivesse sido confiada aos cuidados da Marquesa de Sévigné que de uma moça encerrada em quatro paredes, sem outro horizonte que não fosse o seu amor, «"trop grand pour un seul être" (Rilke), e o céu cru do Alentejo» (p. 13-14).

A «magnífica música» deste coração de mulher exasperado de amor teve porém a sorte de uma outra escuta. Com efeito, uma excepção e uma voz de excepção face a este coro de vozes que consagrará para todo o sempre o mito de Mariana Alcoforado será a de Rilke: impressionado pela beleza desta obra, tocado no coração pelas mulheres que ousaram amar sem serem correspondidas - como Mademoiselle de Lespinasse, como Gaspara Stampa, como Louize Labé, como Maria Madalena -, traduzirá, também ele, em 1930, as Cartas Portuguesas em alemão. E a controvérsia em torno da autenticidade do autor ou da autora das Cartas não deterá a atenção de Rilke. O que verdadeiramente o tocará no pequeno livro, o que vivamente tocará este poeta cuja meditação sobre o amor assedia toda a sua obra, das Lettres à un jeune poète às Élégies de Duine, sem esquecer os Cahiers de Malte Laurids Brigge, será o coração exasperado de Mariana falando a voz nua - esta «mulher admirável entre todas» na sua incondição de «grande apaixonada»e «de amante abandonada». Nas Cartas Portuguesas, Rilke não sublinha senão a majestade de um amor levado ao extremo pela desolação da separação e pelo abandono do amado : tal é para ele a magnificência da «religiosa portuguesa» : «o exemplo da portuguesa é de uma pureza maravilhosa», escreve Rilke, «pois ela não projecta as vagas do seu sentimento na imaginação, mas com uma força infinita conduz a si própria a genialidade deste sentimento : suportando-o e nada mais. Envelheceu num convento, mas não se tornou santa, nem sequer uma religiosa exemplar. Era odioso ao seu tacto precioso dedicar a Deus aquilo que não lhe estava destinado, aquilo que o conde de Chamilly pôde desdenhar. [...] Se esta mulher, admirável entre todas, tivesse cedido por um leve momento, teria caído 
ternamente Rilke soube cantar o furor da audácia do seu amor «demasiado grande para um só ser».

«Acontecia com eles o mesmo que com a madressilva, que se enrolava à volta da avelaneira; a ela enlaçada e ligada ao tronco podem viver assim muito tempo juntas. Mas de seguida, se se tenta separá-las, a avelaneira morre de pronto e o mesmo se passa com a madressilva. "Querida amiga, assim é connosco: nem vós sem mim, nem eu sem vós"» ${ }^{60}$

Tal como Romeu e Julieta, Tristão e Isolda figuram também o amor «para a vida, para a morte», «o amor forte como a morte», mais forte do que a morte - na peugada do magnífico Cântico dos Cânticos é o que figura também a belíssima lenda da madressilva, ou da roseira e da videira que, para além da morte, reúnem para a eternidade os túmulos separados dos dois amantes. Talvez mais do que o amor mais forte do que a morte, Tristão e Isolda figurem a «morte de amor(es)».

Lembremos, para começar, que o devaneio musical de Wagner começa com o pronúncio da morte - com uma certa «vela negra», sinal de luto, «que esvoaça rumo ao desenlace». Uma «vela negra» que nos recorda, a nós humanos, o que nós bem gostaríamos de esquecer: a saber: que, por muito forte que seja o amor que une Tristão e Isolda, eles morrem sós e separadamente. Não morrem juntos, mas a contratempo. Como Romeu e Julieta - que Jacques Derrida designa de «heróis do contratempo na nossa mitologia» ${ }^{61}$-, Tristão e Isolda dir-se-iam igualmente «heróis do contratempo» - contratempo que é a forma e a condição do amor. Tal como a do desejo e a da amizade. Di-lo-íamos mesmo a lei inflexível e fatal da relação ao outro em geral. Magnetizando a axiomática de todo o duelo, e mostrando também como o impossivel é bem o paradigma do amor, o contratempo figura a condição de im-possibilidade da relação ao outro como outro. Contratempo que na sua

em Deus como uma pedra no mar, e se Deus tivesse querido experimentar nela o que não pára de fazer com os anjos, se tivesse projectado nela todo o seu esplendor, estou certo de que na aldeia, onde ela está, nesse triste convento, ter-se-ia tornado um anjo, de um momento para o outro, até ao fundo do seu ser».

60 «Il en était d'eux comme du chèvrefeuille qui s'enroulait autour du coudrier ; une fois qu'il s'y est enlacé et qu'il s'est attaché au tronc, ils peuvent longtemps vivre ensemble. Mais ensuite, si on cherche à les séparer, le coudrier meurt aussitôt et le chèvrefeuille pareillement. "Belle amie, il en est ainsi de nous : ni vous sans moi, ni moi sans vous !"’, Marie de France, Lai du Chèvrefeuille in: Tristan et Iseut - Les Poèmes Français - La Saga Norroise, textes originaux, traduits par Daniel Lacroix et Philippe Walter, (Paris: Lettres Gothiques, 1989), 316.

61 «[...] les héros du contretemps dans notre mythologie», Jacques Derrida, «L'aphorisme à Contretemps» in: Psyché. Inventions de l'Autre, (Paris: Galilée, 1987), 519-533. 
admirável e fatal densidade não significa, porém, como Maurice Blanchot o adverte,

«[...] o fracasso do amor num caso singular, mas antes a realização de todo o verdadeiro amor, que seria a de realizar-se no modo da perda, quer dizer, a de realizar-se perdendo, não o que nos pertenceu, mas o que nunca se teve, pois o "eu" e "o outro" não vivem no mesmo tempo, jamais estão juntos (em sincronia), não poderiam por conseguinte ser contemporâneos, mas separados (mesmo unidos) por um "ainda não" que vai a par com um "não mais"» 62.

Juntos, mas ainda não - sempre ainda não: eis a lei do amor. A lei da impaciência e do desfalecimento alimentício do desejo. Tal como a lei do poema, que R. Char diz ser «o amor realizado do desejo que permanece desejo» ${ }^{63}$. O contratempo significa assim a singular impossibilidade do amor: «o que não significa» - haverá que enfatizá-lo, contra a doxa de uma certa compreensão niilista ou niilizante, uma vez mais com as palavras avisadas de Maurice Blanchot onde, uma vez mais, se pressente também o eco de Emmanuel Levinas e de Paul Celan - «o que não significa», pois, dizíamos,

«[...] que amar não se viva senão no modo da espera e da nostalgia, termos que se reduzem demasiado facilmente a um registo psicológico, ao passo que a relação que aqui está em jogo não é mundana, supondo mesmo a desaparição, até mesmo o desmoronamento do mundo. Relembremos as palavras de Isolda: "Nós perdemos o mundo, e o mundo a nós". E relembremos ainda que mesmo a reciprocidade da relação de amor, tal como a história de Tristão e Isolda a representa, paradigma do amor partilhado, exclui tanto a simples mutualidade quanto a unidade na qual o Outro se fundiria no Mesmo. $\mathrm{O}$ que é pressentir que a paixão escapa à possibilidade, escapando, àqueles por ela arrebatados, aos seus próprios poderes, à sua decisão e mesmo ao seu "desejo", nisso a própria estranheza, não atendendo nem ao que podem nem ao que querem, mas atraindo-os para o estranho onde eles se tornam estrangeiros a si próprios, numa intimidade que os torna, também, estranhos um ao outro. Assim, portanto, eternamente separados, como se a morte estivesse neles, entre eles? Não separados, nem divididos: inacessíveis e, na inacessibilidade, numa relação infinita.» ${ }^{64}$

$62 «[\ldots]$ l'échec de l'amour dans un cas singulier, mais l'accomplissement de tout amour véritable qui serait de se réaliser sur le mode de la perte, c'est-à-dire de se réaliser en perdant, non pas ce qui vous a appartenu, mais ce qu'on n'a jamais eu, car le «je» et «l'autre» ne vivent pas dans le même temps, ne sont jamais ensemble (en synchronie), ne sauraient donc être contemporains, mais séparés (même unis) par un «pas encore» qui va de pair avec un «déjà plus»», Maurice Blanchot, «La Communauté des Amants» in: La Communauté Inavouable, (Paris : Minuit, 1983), 71.

63 «[...] l'amour réalisé du désir demeuré désir», René Char, Fureur et Mystère, (XXX), (Paris: Gallimard, 1967), 3.

64 «[...] ce qui ne signifie pas qu'aimer ne se vit que sur le mode de l'attente ou de 
Um tal contratempo revela-se assim a própria respiração do amor, se o há, na ternura das suas impaciências, dos seus arrebatamentos, dos seus furores e desfalecimentos - sem servilismo, avançando a fugir na magnificência do seu excesso ...

Eis então o teatro desta singular im-possibilidade do amor, de que Tristão e Isolda nos fazem a cena, a fim de sublinhar, ao rés da letra desta tragédia, como segundo Derrida «o maior amor nasce da maior força de dissociação». Como a separação sem reparação é a respiração, a condição de possibilidade, numa palavra, o próprio hímen ${ }^{65}$ do amor. Voltemo-nos então agora para Tristão e Isolda e comecemos muito sucintamente por lembrar que, depois de muito resistirem a um tal destino, os dois amantes são levados a separarem-se: Isolda vive na corte do Rei Marco e Tristão, uma vez regressado à Bretanha, casou com uma outra Isolda - a das Mãos Brancas. Casamento que, de acordo com algumas narrativas, não terá sido consumado. Então, ferido de morte aquando de um combate, Tristão confia em segredo a Kaherdin, seu cunhado, amigo e confidente - que figura aqui o terceiro (terstis, testis) -, a missão de ir buscar Isolda à Cornualha. Só ela o poderia curar. E combinam entre si um sinal: se Kaherdin trouxer Isolda consigo deverá içar uma vela branca e, no caso contrário, uma vela negra.

Nesta história de vela negra e vela branca, como não deixar vir também à memória a lenda do héroi ateniense, Teseu, que, à sua «chegada à vista da costa de Ática», «em total desolação pela perda de Ariadne, se esqueceu de trocar as velas negras do navio e de hastear a vela branca, sinal de vitória» (cf. Grimal), fazendo assim Egeu, o pai que o aguardava, precipitar-se no

la nostalgie, termes qui se réduisent trop facilement à un registre psychologique, alors que la relation qui ici est en jeu n'est pas mondaine, supposant même la disparition, voire l'effondrement du monde. Rappelons-nous la parole d'Iseult : "Nous avons perdu le monde, et le monde nous." Et rappelons-nous encore que même la réciprocité du rapport d'amour, tel que le représente l'histoire de Tristan et d'Iseult, paradigme de l'amour partagé, exclut aussi bien la simple mutualité que l'unité où l'Autre se fondrait dans le Même. Ce qui vient à pressentir que la passion échappe à la possibilité, échappant, pour ceux qui en sont saisis, à leurs propres pouvoirs, à leur décision et même à leur "désir", en cela l'étrangeté même, n'ayant égard ni à ce qu'ils peuvent ni à ce qu'ils veulent, mais les attirant dans l'étrange où ils deviennent étrangers à eux-mêmes, dans une intimité qui les rend, aussi, étrangers l'un à l'autre. Ainsi donc, éternellement séparés, comme si la mort était en eux, entre eux? Non pas séparés, ni divisés : inaccessibles et, dans l'inaccessible, sous un rapport infini», Blanchot, «La Communauté des Amants» in op. cit., 71-72.

65 «Avec toute l'indécidabilité de son sens, l'hymen n'a lieu que quand il n'a pas lieu, quand [...] le voile est déchiré sans l'être», Jacques Derrida, «La double Séance» in: La Dissémination, (Paris : Seuil, 1972), 245, 241. 
mar que doravante porta o seu nome? Justamente ligada ao nascimento da língua, à vinda do pensamento às palavras, esta história de velas vem, pois, de muito longe na nossa memória ocidental - para nada aqui dizer também, não das velas, mas dos tantos véus da Bíblia (Ex., XXVI, 31; Mat., XXVII, 51; Luc., XXIII, 5; Marc., XV, 38). No verão passado, dizia-me um amigo grego, leitor e tradutor de Jacques Derrida, que é sobretudo o mito de Egeu que vem à memória dos gregos quando, a partir da altura do cabo Sunião, contemplam ao longe, através das ruínas assombradas do templo de Posídon, a linha azul do encontro abissal do céu e do mar, ao passo que um filósofo que por ali passe pensa sobretudo em Sócrates: terá de facto sido, algures, ali que, na mais estrita obediência às leis da polis - ele que poderia ter ficado na história da filosofia como o primeiro dissidente 66 ! -, Sócrates terá pacientemente esperado a hora da morte (que, lembremo-lo também, haveria de chegar com o esvoaçar das velas do navio regressado de Delos, assim cumprindo o sonho que Sócrates tinha tido (cf. Criton, 43c-d - 44b; Fédon, 59 d-e) e, preparando-se para ela e assumindo-a (epimeleia tou thanatou), postulado para a eternidade a filosofia como a «maior das músicas» para a alma (Fédon 61a-b). Mas, como também Nietzsche o referiu, a música «arte da noite e da penumbra ${ }^{67}$, a arte da mais absoluta passagem, da perda portanto, que é «uma ferida sempre aberta» ${ }^{68}$ - anda de mãos dadas com a melancolia e com as lágrimas: «Não sei estabelecer diferença entre as lágrimas e a música», confessa Nietzsche, confessando que «não poderia passar sem Rossini, e menos ainda sem o Meio-dia musical, sem a música do meu mestre veneziano Pietro Gasti ${ }^{69}$. Modo de dizer que a música se aproxima sempre da sublimidade do canto do cisne.

Mas regressemos de novo a Tristão e Isolda e à cena do anúncio do contratempo: Isolda, a das Mãos Brancas, a esposa infeliz e ciumenta, acabou no entanto por descobrir o segredo combinado entre Tristão e Kaherdin, e, assim que vislumbra no horizonte o veleiro que, muito atrasado devido às adversidades da natureza, retorna enfim ostentando uma vela branca, correrá a anunciar a Tristão que a vela é negra. A tais palavras, Tristão, que com muito esforço reunia as derradeiras forças para aguentar a espera, deixa-se pura e simplesmente morrer:

«Volta-se para a parede e diz: "Não consigo mais suportar a vida..." Três vezes diz: «Amiga Isolda! À quarta, entrega o espírito.»

66 Cf. J. Derrida, Inconditionnalité ou Souveraineté. L'Université aux frontières de l'Europe, tr. e notas de Vanghélis Bitsoris (Athènes : Éditions Patakis, 2002), 64-66.

67 F.Nietzsche, «Aurore» in Euvres Philosophiques Complètes, textos estabelecidos por Giorgio Colli e Mazzino Montinari (Paris, Gallimard), 35.

68 F. Nietzsche, «O caso Wagner» in Ecce Homo (Lisboa: Guimarães ed.), 151.

69 F. Niezsche, «Porque sou tão sagaz» in Ecce Homo, op. cit., p. 64. 
Mas eis que a provação do afastamento tende ainda a encaminhá-los um para o outro, uma vez que, imersa numa angústia extrema, em razão do grande atraso do veleiro, à chegada Isolda corre para o palácio. A caminho ouve, porém, o dobre de finados:

«Por quem dobram os sinos? Por quê estes choros?», pergunta a si mesma.

Tristão acaba de morrer - e é a cena do contratempo mortífero entre os dois amantes e, portanto, a cena da morte de amor(es):

«Amigo, vendo-vos morto, não posso nem devo querer viver. Morrestes por amor a mim e eu morro de ternura por vós, meu amigo, porque não consegui chegar a tempo [...] Abraça-o e deita-se a seu lado. Beija-lhe a boca, o rosto, e mantém-no estreitamente abraçado. Deita-se, corpo com corpo, boca com boca, e expira. Morre assim a seu lado pela dor causada pela sua morte. Tristão morreu por amor a Isolda que não conseguiu chegar a tempo. [...] e a bela Isolda [morreu] por ternura por ele.

Thomas acaba aqui a sua história $[\ldots] \gg^{70}$

Na narrativa de Heinrich de Freiberg - que completa a versão alemã inacabada de Gottfried de Strasbourg (1210), versões que Richard Wagner melhor conhecia - a distância temporal que separa as duas mortes é ainda mais acentuada. Primeiro, a morte de Tristão é absolutamente fulminante. Assim que ouve anunciar que a vela é negra:

«[...] nesse mesmo instante morreu. A morte partiu-lhe tão bruscamente o coração que ele não conseguiu sequer dizer uma única palavra $[. .$.$] nem$ mesmo 'ai de mim!', nem mesmo 'que desgraça!' [...]»

Quanto a Isolda: quando acompanhada de Kurneval chega enfim ao porto, as exéquias de Tristão já começaram. O seu corpo já está exposto na catedral, e por toda a cidade se fazem ouvir as honras fúnebres - e eis a outra cena do contratempo e do morrer de amor(es):

«Ali, ambos ouviram por toda a parte, por todos os lados, as pessoas a lamentarem-se e os sinos a tocarem. O que os inquietou e imediatamente questionaram [...] a respeito do senhor Tristão. [...] Kurvenal olhou Isolda com desespero: a sua luminosa tez rosa logo empalideceu, e todas as suas forças a

70 «Ami, vous voyant mort, je ne peux ni ne dois souhaiter vivre. Vous êtes mort par amour pour moi et je meurs de tendresse pour vous, mon ami, parce que je n'ai pu arriver à temps. [...] Elle le serre dans ses bras et s'étend à côté de lui. Elle lui baise la bouche, le visage et le tient étroitement enlacé. Elle s'étend, corps contre corps, bouche contre bouche, et rend l'âme. Elle meurt ainsi à côté de lui pour la douleur causée par sa mort. Tristan mourut par amour pour Yseut qui ne put arriver à temps. [...] et la belle Yseut [mourut] par tendresse pour lui.Thomas achève ici son histoire [...]», Thomas, Le Roman de Tristan, in: Tristan et Iseut - Les Poèmes Français - La Saga Norroise, op. cit., 477-483. 
abandonaram, de tal forma que caiu no chão, desmaiada. Dos seus olhos nem uma única lágrima corria: o seu corpo e o seu coração haviam petrificado [...].

Recuperou um pouco as forças, mas tão pouco que mal se sabia se ela ainda estava viva. A rainha prometida à morte por amor fez um gesto em direcção da catedral [...], teria morrido de pronto, se o desejo, se a esperança de ver ainda uma vez o corpo morto de Tristão não a tivesse mantido viva. Kurvenal [...] conduziu-a até à catedral. Durante todo esse tempo ela não disse uma palavra, nem ai de mim! Nem que desgraça! Contentou-se em apontar com o dedo o leito onde jazia o cadáver de Tristão [...] Levantou primeiro o véu de seda que cobria o rosto do morto para contemplar com atenção os seus traços. Depois atirou-se para cima dele para, no mesmo gesto, boca com boca, face com face, com os seus braços brancos e finos enlaçar o corpo do morto, de tal modo que os golpes da lança da morte trespassaram o seu coração. [...] A morte partiu em dois o coração de Isolda. Ela não disse uma única palavra, nem ai de mim! Nem que desgraça! Nem que desgraça! Nem ai de mim! $J a-$ zia morta em cima do morto. No seu corpo agonizante, o coração da mulher morta de amor partiu-se tão completamente que se tinha a impressão de que mil galhos de madeira seca crepitavam no ardor do braseiro» ${ }^{71} \mathrm{Eu}$ sublinho.

Constatamos que a morte chega mais lentamente na narrativa de Thomas - onde deixa ainda, a cada um, o tempo da lamentação. Ademais, o corpo morto de Tristão parece não estar ainda rígido e o abraço de Isolda pode ter ainda uma terna docura amorosa. Na narrativa de Heinrich de Freiberg, pelo

71 «Là, tous deux entendirent partout, de tous côtés, les gens se lamenter et les cloches sonner. Cela les inquiéta et aussitôt ils questionnèrent [...] à propos du seigneur Tristan. [...] Kurvenal regarda Isolde avec désespoir : son lumineux teint de rose aussitôt pâlit, et toutes ses forces la quittèrent, si bien qu'elle tomba sur le sol, évanouie. De ses yeux clairs ne coulait pas une seule larme : son corps et son cœur avaient été pétrifiés [...].

Elle recouvra un peu de forces, mais si peu qu'on savait à peine si elle était encore en vie. La reine promise à la mort d'amour, fit un geste en direction de la cathédrale [...], elle serait morte aussitôt, si le désir, si l'espoir de voir encore une fois le corps mort de Tristan ne l'avait maintenue en vie. Kurvenal [...] la conduisit jusqu'à la cathédrale.

Pendant tout ce temps elle ne dit pas un mot, ni hélas ! ni malheur !, elle se contenta de montrer du doigt la civière où reposait le cadavre de Tristan. [...] Elle enleva d'abord le voile de soie qui recouvrait le visage du mort, pour contempler avec attention ses traits. Puis elle se jeta sur lui pour, dans le même geste, presser sa bouche contre sa bouche, sa joue contre sa joue; de ses bras blancs et fins elle enlaça le corps du mort, si bien que les coups de la lance de la mort transpercèrent son cœur. [...] La mort brisa en deux le cœur d'Isolde. Elle ne dit pas un seul mot, ni hélas ! Ni malheur! Ni malheur ! Ni hélas ! Elle gisait morte sur le mort. Dans son corps agonisant, le cour de la femme morte d'amour se brisa si bien qu'on avait l'impression que mille brindilles de bois sec craquaient dans l'ardeur du brasier...», Heinrich de Freiberg, Deuxième Continuation (continuação de Tristan et Isolde, inacabado, de Gottfried de Strasbourg, em parte composto a partir do Roman de Tristan de Thomas), in Tristan et Yseut - Les premières Versions Européennes, (Paris: Gallimard, 1995), 773-775. 
contrário, a morte tem a dureza e a contundência de um golpe - deixa sem voz e é já um cadáver que Isolda abraça.

Terrível imagem, esta, de um coração que se parte na violência do choque da chama e do gelo, do frio da morte e do ardor do amor! Mas, como dizia o célebre Rabino Nachman de Breslau citado por Elie Wiesel, «nenhum coração está tão inteiro quanto um coração partido»...

Meditando esta dupla narrativa de Tristão e Isolda, perguntemo-nos: onde se encontra a maior solidão dos amantes? No monólogo do lamento, ou no mutismo da palavra cortada? No terno e vão abraço de um corpo que já não responde, ou no golpe mortal que vem desse corpo morto? Quem ousará dizer onde reside a maior distância? A mais terrível separação? A mais incomensurável solidão? É bem a cena dos três «S» que talham a singularidade do vivente humano que aqui confrontamos - o $s$ da separação, o $s$ da solidão e o $s$ do segredo ou do silêncio. Três «S» que desenham aquilo a que Emmanuel Levinas, no alheamento de qualquer confeccionismo religioso, chama «ateísmo» ${ }^{72}$ - o preço da própria singularidade mortal e a condição de possibilidade de toda e qualquer relação ao outro seja ele quem for.

Certo é que, nos dois casos, nas duas versões, tão invisível como um véu transparente, como o ar que se respira, uma distância intransponível cavou-se em abismo entre os dois corpos e os dois corações que, até aí, pareciam bater em uníssono. Mas acaso não é esta cena a «fotografia enlutada da festa» da nossa condição humana? Do trágico da nossa humana incondição? De um sublime à medida do humano? Com efeito, não esteve uma tal distância sempre ali? Entre eles os dois? Em cada um deles os dois mesmo? Interrompendo a aliança do par, do duo, tanto quanto a de cada membro do duo ou do par? Esta distância, contra a qual o amor embate e se parte, mas sem a qual não haveria também amor, este contratempo - a invariante de todos os relatos de amor - trá-la manifestamente à luz sob a sombria claridade da melancolia. Fazendo-o, uma tal distância manifesta, muito para além do seu carácter meramente acidental, um contratempo essencial. Absolutamente essencial. Tal como acontece com Romeu e Julieta, poder-se-ia dizer com Jacques Derrida que o acidente anacrónico, que «o contratempo acidental vem [justamente] sublinhar o contratempo essencial», que ele põe a nu sob os nossos olhos incrédulos, uma vez que «também não há encontro sem o espaçamento do contratempo». Em Romeu e Julieta o contratempo acidental, que está na origem do encontro falhado, do acidente infeliz, resultou, lembremo-lo, do desvio e do atraso de um carta que acaba por não chegar a tempo ao destino. Um terceiro, bem-intencionado, sem dúvida, mas demasiado confiante, Frei Lourenço, que casou Romeu e Julieta, confia a carta,

72 «On peut appeler athéisme cette séparation si complète que l’être séparé se maintient tout seul dans l'existence sans participer à l'Être dont il est séparé.», E. Levinas, Totalité et Infini (Paris : Kluwer Academic Publ., 1998), 52. 
que deveria salvá-los, a um mensageiro que é detido no caminho, e a mensagem acaba por chegar tarde. Demasiado tarde. Em Tristão e Isolda é também um terceiro mal-intencionado - a esposa ciumenta, Isolda das Mãos Brancas - que transforma a mensagem no seu contrário, transformando assim o remédio em veneno. Terceiro antes figurado pela generalidade da linguagem. Nos dois casos, porém, o schibboleth, a senha ou o sinal da salvação é desviado e não chega nem aos destinatários nem ao seu telos - a saber, a salvar da morte. O sinal da salvação não salva. Não chega a tempo. Não chega a tempo ao tempo. E assim, não só os amantes não serão salvos da morte, como nem sequer morrem juntos. É o contratempo absoluto! O morrer de amor(es), como todo o morrer, é um morrer solitário - morre-se só. Morre-se sempre só. Muito só. De uma certa maneira, está-se aliás sempre só. Muito só. «Penso em ti! Estou aqui... Não estás só! Não estás só! Estás aqui... Não estou só! Penso em ti!» Eis o «refrão» que embala os apaixonados! Todos os apaixonados! Como a criança no escuro, eles sonham com a euforia da plenitude do encontro, com a transparência da união, com a intimidade absolutamente partilhada, como Tristão terá, ele também, sonhado com um palácio de vidro, com um espaço de pura transparência, onde Isolda e ele poderiam amar-se «para a vida, para a morte». Palácio que não deixa de evocar a maravilhosa ilha da Fata Morgana onde os amantes se refugiam - e, talvez ainda mais, a famosa «ilha de vidro», que, entre os celtas, é também o país dos mortos, a terra da promessa. Tais moradas não são porém daqui - deste mundo. Neste mundo, no nosso mundo, e, no rastro do sublime Die Welt ist fort, ich muss dich tragen de Celan, como a própria origem ou o próprio fim do mundo ${ }^{73}$, a união, a relação, o encontro, a partilha implicam a partição, a separação, o afastamento, a solidão, a não-coincidência... Não há partilha sem partição. Não há relação sem «sem relação». Não há relação sem interrupção, sem ininterrupta interrupção, sem separação. Não há união, não há acordo que reúna sem disjunção, sem interrupção. Sem uma separação irreparável. E tal é a condição da relação ao outro como outro ${ }^{74}$. Como outro ab-soluto

73 Cf. Jacques Derrida, Béliers, Paris : Galilée, 2003 [NT : Carneiros - o Diálogo Ininterrupto : entre dois infinitos, o poema, tr. Fernanda Bernardo, Coimbra : Palimage, 2008].

74 «Cette scène peut être tenue pour le paradigme de tout rapport à l'autre, quel qu'il soit, humain ou divin. Avoir rapport à l'autre comme autre, n'est-ce pas, dans la séparation ou dans l'interruption, tenir à un autre, tendre, se tendre vers lui, là où il ne peut se montrer qu'en ne se montrant pas ? Le rapport à l'altérité en général, cette expérience d'une invisibilité dans le visible, où la non-phénoménalité est nécessaire, c'est une sorte d'interruption de soi par la phénoménologie [...] On n'a pas d'accès à l'ici-maintenant de l'autre, de l'autre côté, au point zéro de cette autre origine du monde - et c'est la condition de l'expérience de l'autre comme autre. Cette déliaison première au cœur du lien social, et comme condition du lien social, elle tient d'abord à l'altérité de l'autre : celui-ci ne se présente comme autre qu'à ne se jamais présenter comme tel, autre comme 
(ab-solus), quer dizer, separado! Tal é também a condição da amizade, do desejo e do amor, ou, mais precisamente talvez, tal é também $a$ condição aporética do amor: «se eu amasse seria de longe, de tempos a tempos, separadamente», escreve Hélène Cixous na sua Histoire du Contretemps, dando-nos também a ler e a pensar a separação absoluta como o destino e a própria loco-comoção do amor - do puro e extra-ordinário élan amoroso:

«Não nasci para a felicidade», escreve Cixous como que num eco de Wagner, «a minha alma é-lhe estranha. O casamento matar-nos-ia. Amando-vos de demasiado perto, muito depressa me habituaria, e o amor cessaria. Se eu amasse seria de longe, de tempos a tempos, separadamente» ${ }^{75}$

Mas como é que se pode amar "separadamente"?, pergunta-se Jacques Derrida, que logo acrescenta:

«[...] mas como é que se pode amar senão "separadamente"? Cada um o outro, mas de cada vez cada um para si, cada um no segredo, cada um em segredo, no mais forte do amor. O outro, no fundo, nada pode saber, nada pode alguma vez aperceber, nem mesmo algo a que se chame ver. Não se pode amar separadamente e não se pode amar senão separadamente, na separação ou no desemparelhamento do par. A uma distância infinita, porque incomensurável: eu não estarei nunca à mesma distância - de ti, que tu, que tu de mim. Não há medida comum, não há simetria. Separação infinita no próprio casal e na paridade do par.» ${ }^{76}$

A separação afigura-se assim o éter e a respiração do amor, a sua própria possibilitação. A sua singular im-possibilidade. Amor que, ainda no dizer de Jacques Derrida, se descobre assim «a conjugação de dois desejos aforísti$\cos$, mas mantidos juntos, mantidos no agora deslocado ${ }^{77}$ de uma anacronia

autre. Autrement dit, sa manière de se présenter consiste à ne pas se présenter. N'est-ce pas là la condition du rapport à l'autre, quel qu'il soit, X, l'animal, Dieu ou l'homme ?», Jacques Derrida, «Fidélités à plus d'un» in Idiomes, Nationalités, Déconstruction : Rencontre de Rabat avec Jacques Derrida, Les Éditions Toubkal/Cahiers Intersignes, numéro 13 automne 1988, 226.

75 Citado por J. Derrida in «Fourmis» in colectivo, Lectures de la Différence Sexuelle (Paris: Ed. des Femmes, 1994), 82.

76 «[...] mais comment peut-on aimer autrement que "séparément"? Chacun l'autre, mais chaque fois chacun pour soi, chacun au secret, chacun en secret, au plus fort de l'amour. L'autre au fond n'en peut rien savoir, jamais rien percevoir, ni même jamais rien qui s'appelle voir. On ne peut aimer séparément et on ne peut aimer que séparément, dans la séparation ou le dépareillement de la paire. À une distance infinie, parce que incommensurable : je ne serai jamais à la même distance - de toi, que toi, que toi de moi. Pas de commune mesure, pas de symétrie. Séparation infinie dans le couple même et dans la parité de la paire.», Jacques Derrida, «Fourmis» in op. cit., p. 83.

$77 \ll[\ldots]$ la conjonction de deux désirs aphoristiques, mais tenus ensemble, maintenus 
irredutível: não há amor sem esta «separação» irreparável, sem esta «discordância», sem o abismo desta noite escura, deste vertiginoso vazio. E é justamente por isso que o contratempo não é apenas algo de acidental ao amor, mas algo de absolutamente essencial - ele acicata o desejo à sua nascença, tanto quanto alimenta a fome insaciável do outro, pelo outro, para o outro:

«Amo», escreve Jacques Derrida em «L'Aphorisme à Contretemps», «amo porque o outro é outro, porque o seu tempo não será nunca o meu. A duração viva, a própria presença do seu amor permanece infinitamente afastada da minha, afastada dela própria naquilo que a inclina para a minha, e, isto, mesmo naquilo que gostaria de descrever-se como a euforia amorosa, a comunhão extática, a intuição mística. Não posso amar o outro senão na paixão deste aforismo. Este não advém, não sobrevém como desventura, desgraça ou negatividade. Tem a forma da afirmação mais amante - é a chance do desejo.» ${ }^{78}$

O aforismo é portanto a chance do desejo, a promessa ou o próprio sonho do amor - de facto, observa ainda J. Derrida, «inversamente, não há contratempo, não há aforismo sem a promessa de um agora comum, sem o juramento, sem o voto de sincronia, sem a partilha desejada de um presente vivo.» ${ }^{79}$

Mais liminarmente ainda: a separação não se revela apenas o recurso alimentício do amor: é a condição da relação ao outro como outro. É o destino do duo, do duelo, do casal, do par, tanto quanto da relação do eu a si mesmo como um outro. Hetero-afectado! Hetero-auto-afectado! A separação é o destino de todos os «uns» e de todos os «dois» que, por isso, em si mesmos, são já sempre «mais de um(a)» ${ }^{80} \mathrm{e}$ «mais do que um(a)». Como, cada um à

dans le maintenant disloqué», Jacques Derrida, «L'aphorisme à Contretemps» in Psyché. Inventions de l'Autre (Paris : Galilée, 1987), 522.

78 «J'aime parce que l'autre est l'autre, parce que son temps ne sera jamais le mien. La durée vivante, la présence même de son amour reste infiniment éloignée de la mienne, éloignée d'elle-même dans ce qui la tend vers la mienne, et cela jusque dans ce que l'on voudrait décrire comme l'euphorie amoureuse, la communion extatique, l'intuition mystique. Je ne peux aimer l'autre que dans la passion de cet aphorisme. Celui-ci n'advient pas, il ne survient pas comme le malheur, la malchance ou la négativité. Il a la forme de l'affirmation la plus aimante - il est la chance du désir.», Ibid., 523.

79 «[...] inversement, pas de contretemps, pas d'aphorisme sans la promesse d'un maintenant commun, sans le serment, le vœu de synchronie, le partage désiré d'un présent vivant.», Ibid.

80 A divisibilidade do «eu», do «sujeito» ou da «pessoa», em si sempre «mais de um/a», é abordado nos seguintes termos por H. Cixous em Jours de l'an (Paris : Éd. des Femmes, 1990), p. 162-163: «L'auteur: J'ai besoin de parler de ces femmes qui en moi sont entrées, elles m'ont frappée, elles m'ont fait mal, elles ont réveillé en moi les morts, elles ont frayé des chemins, elles m'ont apporté des guerres, des jardins, des enfants, des familles étrangères, des deuils sans tombe, et j'ai goûté le monde dans leurs langues.

En moi elles ont vécu leurs vies. Elles ont écrit [...]. Elles continuent, ne cessant de 
sua maneira, Romeu e Julieta e Tristão e Isolda bem o atestam.

«A certeza absoluta que reina sobre o duelo (sendo Romeu e Julieta a encenação de todos os duelos im-possíveis)», escreve Jacques Derrida, «é a de que um deve morrer antes do outro. Um deve ver morrer o outro. A não importa quem eu devo poder dizer: uma vez que somos dois, sabemos de maneira absolutamente inelutável que um de nós morrerá antes do outro. Um de nós verá o outro morrer, um de nós sobreviverá, nem que seja por um instante. Um de nós, um de nós somente, portará a morte do outro - e o seu luto. É impossível que sobrevivamos ambos um ao outro. Eis o duelo, a axiomática de todo o duelo, a cena mais comum e a menos dita - ou a mais interdita - da nossa relação ao outro.» ${ }^{81}$

Em Romeu e Julieta, o estrategema do simulacro da morte de Julieta, encenado por Frei Lourenço, faz com que o impossível aconteça, com que ele tenha lugar no teatro, quer dizer, faz com que cada um dos amantes sobreviva, por um mero instante - não mais do que o tempo de se dar a morte -, à morte do outro. Faz com que eles vivam à vez, cada um por sua vez, a morte do outro e portem assim por momentos cada um o luto do outro: Romeu morre antes de Julieta, que viu morta. Vivem, sobrevivem portanto ambos à morte do outro. Velam assim ambos a morte do outro na própria morte do outro $^{82}$. O que obviamente não é possível senão no teatro. Mas este artifício teatral levanta o pano para esta outra verdade, que não é senão o corolário da precedente: a saber, que amar o outro é sabê-lo mortal, que, sem esperar embora a morte do outro, o amor, todo o amor está de antemão sempre enlutado. Luto do amor como luto do outro e como luto de si. Luto que mais não diz do que a doce proximidade ao outro amado na separação. Luto que diz a separação do outro amado na mais próxima e amante das proximidades. Eis a lei do amor, se o há, quando o há. Eis o veredicto de uma finitude re-afirmada. Eis, enfim, uma sublimidade à medida da nossa pobre finitude

vivre, ne cessant de mourir, ne cessant d'écrire [...],

Je ne peux pas dire que nous vivons là où la proximité tourne en séparation. Parce que je ne sais même pas.

Entre nous, où est la vérité ? Elle est entre nous. Elle est dans cet emmêlement de coups et de caresses que je ne peux même pas contempler sans frayeur.».

81 «La certitude absolue qui règne sur le duel, c'est que l'un doit mourir avant l'autre. L'un doit voir mourir l'autre. À n'importe qui je dois pouvoir dire : puisque nous sommes deux, nous savons de façon absolument inéluctable que l'un de nous mourra avant l'autre. L'un de nous verra l'autre mourir, l'un de nous survivra, ne fût-ce qu'un instant. L'un de nous, l'un de nous seulement, portera la mort de l'autre - et son deuil. Il est impossible que nous survivrons tous deux l'un à l'autre. Voilà le duel, l'axiomatique de tout duel, la scène la plus commune et la moins dite - ou la plus interdite - de notre rapport à l'autre.», Ibid., p. 524.

82 Cf. Ibid. 
mortal: «se morreres antes de mim, eu guardar-te-ei, se eu morrer antes de ti, tu portar-me-ás em ti, cada um guardará o outro»:

«Desde o juramento que liga dois desejos - escreve Jacques Derrida - cada um porta já a morte do outro, confia-lhe igualmente a sua morte; se morreres antes de mim, eu guardar-te-ei, se eu morrer antes de ti, tu portar-me-ás em ti, cada um guardará o outro, tê-lo-á guardado desde a primeira declaração.» ${ }^{83}$

O que é declarar, sem qualquer derrotismo, pessimismo ou niilismo, que o amor é à-priori melancólico - uma vez que, como tão enfaticamente J. Derrida $^{84}$ o sublinha, o amor é amor de algo ou de alguém que à partida «sabemos» que vamos perder, quer por o outro morrer um dia, quer por o próprio eu-amante morrer. E no teatro da vida um dos dois morrerá sempre antes do outro - desde que se entra numa relação de amor ou de amizade, numa qualquer relação não importa com quem, sabe-se que um dos dois morrerá sempre antes do outro. Sem tragédia nem derrotismo, tal é a condição do amor entre seres finitos ou mortais - em «La Mélancolie d'Abraham» Derrida di-lo assim:

«[...] no amor há sempre a experiência de uma ruína possível, de uma desaparição possível. Não se pode amar de outra maneira.» ${ }^{85}$

E em «Fidélité à plus d'un», o mesmo Jacques Derrida reafirma a separação ligante do contratempo como condição da própria relação ao outro como outro, qualquer que ela seja e seja ele quem for, na peugada da cena, não da relação (de amor e/ou de fidelidade) de Abraão a Deus, em Genésis 22, como acontece nomeadamente em Dar a Morte ${ }^{86}$, mas, insinuando a desconstrução da inter-subjectividade onto-fenomenológica, na de Moisés que

«[...] pede a Deus para se manifestar («mostra-te»). Deus recusa a visibilidade. Esta cena», advoga Jacques Derrida, «pode ser tida pelo paradigma de toda a relação ao outro, seja quem for, humano ou divino. Relacionar-se com o outro como outro, na separação ou na interrupção, querer bem ao outro, tender, inclinar-se para ele, ali onde ele não pode mostrar-se senão não se mostrando? [...] Não se tem acesso ao aqui-agora do outro, do outro lado, no ponto zero desta outra origem do mundo - e é a condição da experiência do outro como outro. Esta desligação primeira no coração do laço social, e

83 «Dès le serment qui lie deux désirs - écrit Jacques Derrida - chacun porte déjà la mort de l'autre, lui confie sa mort aussi ; si tu meurs avant moi, je te garderai, si je meurs avant toi, tu me porteras en toi, l'un gardera l'autre, l'aura gardé depuis la première déclaration.», Ibid.

84 Cf. J. Derrida in «La Mélancolie d'Abraham», entrevista com Michal Ben-Naftali, in Les Temps Modernes, 67 année, juillet/octobre 2012, nº 669/670, p. 36.

85 Ibid.

86 J. Derrida, Dar a Morte, tr. Fernanda Bernardo (Coimbra: Palimage/Terra Ocre, 2013) 
como condição do laço social, deve-se primeiramente à alteridade do outro: este não se apresenta como outro senão a nunca se apresentar como tal, outro como outro. Por outras palavras: a sua maneira de se apresentar consiste em não se apresentar. Não é isto a lei da relação ao outro, seja ele quem for, $X$, o animal, Deus ou o homem?» ${ }^{87}$

Eu sublinho para, em jeito de conclusão, reafirmar, por um lado, o contratempo como a lei do amor, ou de toda e qualquer relação ao outro como outro - como outro, isto é, respeitado ou amado no absoluto da sua alteridade seja ele quem for -, e, por outro lado, para postular a melancolia ${ }^{88}$, subtraída à ordem da consciência, da presença a si e do ego, como a própria Stimmung do amor.

\section{Tradução \\ Bruno Padilha \\ Inês Almeida \\ Revisão \\ Fernanda Bernardo}

87 «Reprenons l'exemple de Moïse: il demande à Dieu de se manifester («montre-toi»). Dieu refuse la visibilité. Cette scène peut être tenue pour le paradigme de tout rapport à l'autre, quel qu'il soit, humain ou divin. Avoir rapport à l'autre comme autre, n'est-ce pas, dans la séparation ou dans l'interruption, tenir à l'autre, tendre, se tendre vers lui, là où il ne peut se montrer qu'en ne se montrant pas ? [...] On n'a pas d'accès à l'ici-maintenant de l'autre, de l'autre côté, au point zéro de cette autre origine du monde - et c'est la condition de l'expérience de l'autre comme autre. Cette déliaison première au cœur du lien social, et comme la condition du lien social, elle tient d'abord à l'altérité de l'autre: celui-ci ne se présente comme autre qu'à ne se jamais présenter comme tel, autre comme utre. Autrement dit, sa manière de se présenter consiste à ne pas se présenter. N'est-ce pas là la loi du rapport à l'autre, quel qu'il soit, X, l'animal, Dieu ou l'homme?», J. Derrida, «Fidélité à plus d'un» in Idiomes, Nationalités, Déconstructions, Paris/Casablanca : Intersignes/ Ed. Toubkal, 1998, p. 226.

${ }^{88}$ Lembramos que a melancolia é repensada por J. Derrida em termos de luto impossível, o único que é fiel ao outro como outro: «Selon Freud, le deuil consiste à porter l'autre en soi. Il n'y a plus de monde, c'est la fin du monde pour l'autre à sa mort, et j'acueille en moi cette fin du monde, je dois porter l'autre et son monde, le monde en moi: introjection, intériorisation du souvenir (Erinnerung), idéalisation. La mélancolie accueillerait l'échec et la pathologie de ce deuil. Mais si je dois (c'est l'éthique même) porter l'autre en moi pour lui être fidèle, pour en respecter l'altérité singulière, une certaine mélancolie doit protester encore contre le deuil normal. Elle ne doit jamais se résigner à l'introjection idéalisante. Elle doit s'emporter contre ce que Freud en dit avec une tranquille assurance, comme pour confirmer la norme de la normalité. La «norme» n'est autre que la bonne conscience d'une amnésie. Elle nous permet d'oublier que garder l'autre au-dedans de soi, comme soi, c'est déjà l'oublier. L'oubli commece là. Il faut donc la mélancolie. En ce lieu, la souffrance d'une certaine pathologie dicte la loi - et le poème à l'autre dédié.», J. Derrida, Béliers (Paris: Galilée, 2003) 73-74 [p. 52 na tradução portuguesa, Coimbra: Palimage, 2008]. 